\title{
1- Türkçe öğretmen adaylarının gözünden Kıbrıs’ta yabancı dil olarak Türkçe öğretimi
}

\author{
Selime GÜNTAŞı
}

Ahmet GÜNEYLi் 2

\section{Burak GÖKBULUT3}

APA: Güntaş, S.; Güneyli, A.; Gökbulut, B. (2021). Türkçe öğretmen adaylarının gözünden Kıbrıs’ta yabancı dil olarak Türkçe öğretimi. RumeliDE Dil ve Edebiyat Araştırmaları Dergisi, (Ö10), 1-21. DOI: $10.29000 /$ rumelide.1009032.

$\ddot{\mathbf{O z}}$

Bu çalışmada Türkçe öğretmen adaylarının gözünden Kıbrıs’ta yabancı dil olarak Türkçe öğretimini değerlendirmek amaçlanmıştır. Araştırmada yabancı dil olarak Türkçe öğretiminde kazanım, yöntem-teknik vb. ne olması gerektiği, yabancı öğrencilerin Türkçe öğrenirken nasıl güdüleneceği ve kaygılarının azaltılacağı, öğretimdeki sorunlar ve sorunlara ilişkin çözüm önerileri değerlendirilmiştir. Araştırmada nitel yaklaşım ve durum çalışması modeli temel alınmıştır. Araştırmanın çalışma grubu kolay ulaşılabilir durum örneklemine uygun olarak Kıbrıs'ta bir üniversitede öğrenim gören öğretmen adaylarından seçilmiştir. Böylelikle araştırmanın çalışma grubunu üniversite 3. sınıfta öğrenim gören ve yabancı dil olarak Türkçe öğretimi dersini almış 33 öğrenci oluşturmuştur. Araştırmada veri toplama aracı olarak görüşme formu kullanılmış ve içerik analizi gerçekleştirilmiştir. Araştırma bulgularına göre Türkçe öğretmen adayları yabancı dil olarak Türkçe öğretiminin ana dili olarak öğretimine oranla daha zor olduğunu belirtmişlerdir. Öğretmen adayları öğrencileri motive etmek ve kaygılarını azaltmak için öğretim yöntem-tekniklerimateryallerini çeşitlendirmek gerektiğini belirtmişler ve Türk tarihi, coğrafyası ile kültürünü öğreterek dikkat çekmek gerektiğini, ana dili konuşucuları ile vakit geçirecek ortamlar ve etkinlikler düzenlemeyi önermişlerdir. Son olarak sorunlar konusunda, konuşma ve sesletim sorununa, Türkçenin zor bir dil olduğu yönündeki inanışa, sözcük dağarcığının yetersizliğine, dil bilgisi kurallarını ve ekleri doğru kullanamamaya, yabancı dil öğreten Türkçe öğreticilerinin yeterliklerinin tam olmayışına dikkat çekmişlerdir. Yaşanan sorunlara yönelik öğretmen adaylarının çözüm önerilerinin başında öğretim sürecinde bol etkinlik ve uygulama yapılması gelmektedir. Söz konusu önerinin yanı sıra öğretimi basitleştirmek gerektiği üzerinde durulmuş; öğrencileri araştırmaya yönlendirme ve onlara Türkçeyi sevdirmenin öneminden söz edilmiştir. Son olarak öğrencilerin hazırbulunuşluğunu ve ön bilgilerini kullanarak öğretim yapmanın gerekli olduğunu belirtmişlerdir.

Anahtar kelimeler: Yabancı dil olarak Türkçe öğretimi, Kıbrıs, Türkçe öğretmen adayları

Öğr. Gör., Kıbrıs Sosyal Bilimler Üniversitesi, Eğitim Programları ve Öğretim (Lefkoşa, Kıbrıs), selime.guntas@asbu.edu.tr, ORCID ID: 00oo-0001-5594-7259 [Araştırma makalesi, Makale kayıt tarihi: 12.09.2021kabul tarihi: 20.10.2021; DOI: 10.29000/rumelide.1009032]

$2 \quad$ Prof. Dr., Lefke Avrupa Üniversitesi, Türkçe Öğretmenliği (Lefke, Kıbrıs), aguneyli@eul.edu.tr, ORCID ID: oooo-00022168-1795

Doç. Dr., Yakın Doğu Üniversitesi, Türkçe Öğretmenliği (Lefkoşa, Kıbrıs), burak.gokbulut@neu.edu.tr, ORCID ID: oooo0003-3968-9207

RumeliDE Dil ve Edebiyat Araştırmaları Dergisi Osmană̆a Mahallesi, Mürver Çiçeği Sokak, No:14/8 Kadıköy - ÍSTANBUL / TÜRKIYE 34714 e-posta: editor@rumelide.com tel: +90 $5057958124,+902167730616$

Address

RumeliDE Journal of Language and Literature Studies

Osmanağa Mahallesi, Mürver Çiçeği Sokak, No:14/8

Kadıköy - ISTANBUL / TURKEY 34714

e-mail: editor@rumelide.com,

phone: +90 5057958124 , +90 2167730616 


\title{
Teaching Turkish as a foreign language in Cyprus through the view of Turkish teacher candidates
}

\begin{abstract}
In this study, it is aimed to reveal the views of Turkish language teaching undergraduate students studying in Cyprus on teaching Turkish as a foreign language. In the research, the similarities and differences between teaching Turkish as a mother tongue and teaching Turkish as a foreign language, how to motivate foreign students and reduce their anxiety, and the problems in teaching and solution suggestions were evaluated. The research is based on a qualitative approach and case study model. The pre-service teachers, who constitute the study group of the research, are studying at a university in Cyprus and are determined by convenience sampling. Accordingly, the study group of the research consists of 33 students who are studying in the third year of the university and took the course of teaching Turkish as a foreign language. In the research, an interview form is used as a data collection tool and content analysis is carried out. According to the research findings, pre-service teachers stated that teaching Turkish as a foreign language is more difficult than teaching it as a mother tongue. Preservice teachers stated that teaching methods-techniques-materials should be diversified to motivate students and reduce their anxiety; they suggested that it is necessary to raise attention by teaching Turkish history, geography and culture and to organize environments and activities to spend time with native speakers. Finally, they drew attention to the problems of speech and pronunciation, the belief that Turkish is a difficult language, the inadequacy of the vocabulary, the inability to use grammar rules and suffixes correctly, and the incomplete proficiency of Turkish educators who teach foreign languages. On the other hand, the solution suggestions of the pre-service teachers for the problems experienced were such as doing plenty of activities and practices, simplifying the teaching, directing the students to research, making them love Turkish, and teaching by using the readiness and prior knowledge of the students.
\end{abstract}

Keywords: Teaching Turkish as a foreign language, Cyprus, Turkish teacher candidates

\section{Giriş}

Türk Dil Kurumuna göre yabancı dil; bir bireye kendi dili dışında akademik, sosyal ve meslekî anlamda yeterlik kazandırmak için “öğretilen dil” anlamına gelir. Demircan’a (1990) göre yabancı dil, ilk olarak öğrendiğimiz veya edindiğimiz dil dışındaki ikinci dildir. Dünyada her geçen gün yabancı dil öğrenme ve kullanma isteği artmaktadır. Bu isteğin temel sebepleri arasında eğitim, ticari ilişkiler, uluslararası gelişim ve ekonomi ile teknolojik unsurlar yer almaktadır (Demircan, 1990). Dünyada öğrenilmek istenen yaygın diller arasında Türkçe de yer almaktadır. Türkçenin, lehçeleri ve tüm özellikleri bakımından dünya sıralamasında tercih edilen beşinci büyük dil olduğu ortaya konmuştur (Kirazlı \& Ateş, 2016). Bu durum, Türkçenin yabancı dil olarak öğretiminin ne kadar önemli olduğunun göstergesidir.

Türkçenin yabancı dil olarak öğretilmeye ilk olarak Türkiye dışında başlandığı görülmektedir. Başta Almanya olmak üzere birçok Avrupa ülkesinde bulunan kişilerin oralarda bulunan Türklerle iletişim kurmak için yabancı dil olarak Türkçe öğretimine gereksinim duyduğu görülmektedir (Mete, 2015). 1990'lı yıllara gelindiğinde ise Sovyetler Birliği’nin dağılması ile birlikte bağımsız devletler ortaya çımıştır. Bununla birlikte çok sayıda öğrenci Türkiye’ye gelmiş ve Türkçenin yabancı dil olarak öğretimi için önemli adımların atılmasını zorunlu kıldıkları görülmüştür (Uzun, 2012).

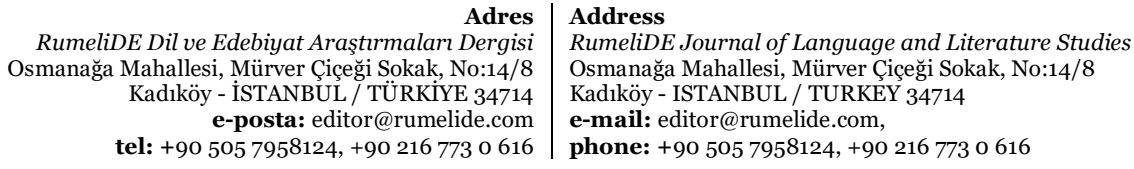


Günümüzde yabancı dil olarak Türkçe öğretiminin 88 farklı ülkede ve birçok uluslararası üniversitede verildiği görülmektedir. Türkiye Cumhuriyeti Millı̂ Eğitim Bakanlığı, Türk İşbirliği ve Koordinasyon Ajansı (TİKA) ve Yunus Emre Enstitüleri aracıllğıyla yurt içi ve yurt dışında yabancı dil olarak Türkçe öğretimine ilişkin önemli çalışma ve projeler yürütülmektedir (Uzun, 2012). Gerek devlet gerek vakıf üniversitelerinde "Sürekli Eğitim Merkezi” ya da “TÖMER” olarak adlandırılan merkezlerde Türkçe yabancı dil olarak öğretilmektedir. Üniversiteler dışında Türkiye Maarif Vakfı adı ile dünyanın çeşitli yerlerinde açllmış olan okul ve merkezlerde Türkçenin yabancı dil olarak öğretildiği görülmektedir. Yurt dışı projelerin yürütülmesini sağlayan ve Türk kültürü ile Türkiye'yi tanıtan Yurtdışı Türkler ve Akraba Toplulukları (YTB) da Türkiye Cumhuriyeti Başbakanlığına bağlı olarak çalışmalarını sürdürmektedir. Bu kuruluşların çalışmalarının yanı sıra Türkçe yeterliliği kazandırmak amacıyla üniversitelerde anabilim dalları açılarak yabancı dil olarak Türkçenin öğretilmesi adına önemli adımlar atıldığı, yüksek lisans ve doktora programları açıldığı görülmektedir (Yıldız \& Tuncel, 2014).

Bu çalışmada ise çok dilli ve çok kültürlü bir ada olan (Aktoprak, Yiğit ve Güneyli, 2018) Kuzey Kıbrıs Türk Cumhuriyeti’nde yabancı dil olarak Türkçe öğretiminin durumunu Türkçe öğretmen adaylarının gözünden değerlendirmek amaçlanmıştır.

\section{Alanyazın}

Kuzey Kıbrıs üniversitelerinde ve daha alt düzeylerdeki eğitim kurumlarında yabancı öğrencilerin sayısındaki artış nedeniyle yabancı dil olarak Türkçe öğretimine ilişkin gereksinim artmıştır. Çeşitli üniversitelerde Türkçe ve edebiyat bölümleri bünyesinde yabancı öğrenciler için Türkçe hazırlık okulları açılmıştır. Üniversite öğrencileri dışında ilköğretim ve ortaöğretim kurumlarında da yabancı öğrencilerin artmasıyla ilköğretimden üniversiteye kadar her kademede yabancı dil olarak Türkçe öğretimi önem kazanmıştır. KKTC'de yabancı dil olarak Türkçe öğretiminin gerçekleştirilmesiyle birlikte akademik çalışmaların sayısında da artış gözlenmiş ve KKTC Milli Eğitim ve Kültür Bakanlığı tarafından öğretim programları geliştirilmeye başlanmıştır.

Kıbrıs'taki yabancı dil olarak Türkçe öğretimi alanındaki ilk akademik çalışmalardan biri Arı'nın (2010) doktora tez çalışmasıdır. Bu çalışmada KKTC'de ilköğretimin ikinci kademesinde öğrenim gören yabancılar için Türkçe öğretimi üzerine bir değerlendirme yapılmıştır. Söz konusu araştırma KKTC'ye yerleşen yabancı öğrencilerin dil beceri düzeyleri belirlenmeden doğrudan ilköğretime alınmaları dolayısıyla yaşanan akademik sorunları tespit edip değerlendirmeye yönelik hazırlanmış bir çalışmadır. Çalışmanın ilk bölümünde tarama modeli kullanılmış ikinci bölümünde ise ön test - son teste dayalı deney ve kontrol gruplu deneysel çalışma modeli kullanılmıştır. Çalışmaya katılan 126 öğretmen ve 118 öğrencinin örneklem olarak belirlendiği çalışmada öne çıkan sonuç, Avrupa Birliği Ortak Dil Kriterleri’nin kullanıldığı Türkçe öğretimine alınan öğrencilerin öğrenme hedeflerine ulaşma düzeyinin, alınmayanlara oranla anlamlı derecede yüksek bulunmuş olmasıdır.

Arı'nın (2013) kitap bölümü olarak hazırladığı diğer bir çalışmasında KKTC'de Türkçeyi yabancı dil olarak kimlerin öğrendiğinden ve ihtiyacın nasıl belirlendiğinden bahsedilmektedir. Buna göre Türkçeyi öğrenmek isteyenler arasında adaya çalışmak için gelip buraya yerleşen kişilerin çocukları, üniversite okumak için adada bulunan yabancı öğrenciler, rahat bir yaşam sürmek için adaya yerleşen orta yaş üzeri İngilizler, 9o'lı yıllarda KKTC'ye özellikle İngiltere ve Avustralya'dan dönüş yapmış Kıbrıslı Türkler ve onların çocukları bulunmaktadır. Arı'ya göre söz konusu farklı grupların Türkçe öğrenme gereksinimlerinin karşılaşılmasında sıkıntılar yaşanmakta ve ihtiyaca yeterli cevap verilememektedir. 
Teaching Turkish as a foreign language in Cyprus through the view of Turkish teacher candidates / S. Güntaş; A. Güneyli; B. Gökbulut (pp. 1-21)

Dağdelen (2015) yüksek lisans tez çalışmasında Doğu Akdeniz Üniversitesi yabancılara Türkçe öğretimi programının dört temel dil becerisi açısından incelenmesini hedeflemiş ve bu amaçla DAÜ Türkçe Hazırlık Bölümünde Türkçe öğrenen 7 öğrenci ve öğretim yapan 4 öğretmenle bireysel görüşmeler yapmıştır. Yeni Hitit kitaplarına göre düzenlenen söz konusu hazırlık okulu programıyla ilgili elde edilen genel sonuca göre; içeriklerin güncel olmadığı, görsellerin az olduğu, dil becerilerini geliştirecek öğrenme yaşantılarının yetersiz olduğu ve programın dilbilgisi yapılarının seviyenin üstünde olduğu belirlenmiştir.

Çiçek (2017) yüksek lisans tezinde KKTC MEKB’ye bağlı okul öncesi eğitim kurumlarında görev yapan 8 okul öncesi öğretmeni ve 2 branş öğretmeni ile görüşmüş, içerik analizi yoluyla görüşmelerden elde edilen verileri değerlendirmiştir. Bu araştırmadan elde edilen sonuca göre Kuzey Kıbrıs'taki okul öncesi kurumlarının eğitim programı, çevre-donanım ve öğretmen yeterliliklerinin yabancılara Türkçe öğretimi bağlamında geliştirilmesi gerekmektedir. Yabancı çocukların ihtiyaç ve sorunlarını giderecek bir programın olmaması öğretmenleri kendi çözüm yollarını üretmeye itmekte ve en önemli sorun öğretmen-öğrenci ile öğretmen veli iletişimsizliği olarak görülmektedir.

Faslı'nın (2018) yükseköğretim düzeyinde yabancı dil olarak Türkçe öğretim programını akademisyen ve öğrenci görüşleri temelinde ele aldığı çalışmasında, Türkçe öğretim programı ve eğitimcilerin sahip olması gereken nitelikler detaylandırılarak irdelenmiştir. Faslı, Patton'un Yetişek Değerlendirme Modeli’ne göre yabancı dil olarak Türkçe öğretimini değerlendirmiş ve KKTC'de yaşanan sorunları belirleyip çözüm önerileri sunmuştur. Araştırma bulgularına göre KKTC'de yabancı üniversite öğrencilerine yönelik Türkçe eğitim programı ve öğretiminde; kazanım, içerik, kültürel değerler, okuma becerisi, yazma becerisi, sözlü anlatım gibi öğrenme-öğretme bileşenlerinin farklı kültürlerden öğrencilerin bireysel farklılıklarına göre düzenlenmesi gerekliliği ortaya konmuştur.

Güneyli ve Gökçebağ (2018) çalışmalarında Türkçeyi yabancı dil olarak öğrenen Kıbrıslı Rumların kaygı düzeylerini incelemişler ve kaygının çeşitli sebeplerini ortaya koymaya çalışmışlardır. Araştırmanın çalışma grubunu Kıbrıs Üniversitesi İnsani Bilimler Fakültesinde Türkoloji bölümünde öğrenim gören ve Türkçeyi seçmeli ders olarak alan 128 üniversite öğrencisi oluşturmaktadır. Nicel araştırma modellerinden genel tarama modelinin kullanıldığı çalışmada Rum öğrencilerin "Yabancı Dil Kaygı Ölçeği”ne göre Türkçe öğrenme kaygı düzeylerinin ortalama bir değerde (2.78/5) olduğu belirlenmiştir. Yabancı dil olarak Türkçe öğrenme süresi uzadıkça öğrencilerin kaygı düzeylerinin azaldığı görülmüştür. Kıbrıslı Türk arkadaşı olan ve Türkçeyi gündelik yaşamında kullanma olanağı yakalayan öğrencilerin de kullanmayanlara oranla kaygı düzeylerinin daha düşük olduğu görülmüştür.

Albayrak ve Erciyas (2019) çalışmalarında KKTC'de Türkçenin yabancı dil olarak öğretimi konusunu incelemişler ve Türkçenin yabancı dil olarak öğretildiği kurumların yöneticileriyle görüşerek gözlemler yapmışlardır. Çalışmanın genelinde KKTC'deki kurum ve kuruluşların kısa tarihçeleri öğretmenlerin uzmanlık alanları, ortalama öğrenci sayıları, fiziki şartlar vb. hususlar ayrıntılı olarak açıklanmıştır.

Egeli ve Barut (2020) makalelerinde ana dili Türkçe olmayan yabancı uyruklu öğrencilerin okul ortamında yaşadıkları problemleri belirlemeye çalışmışlardır. Açık uçlu sorulardan oluşan yarı yapılandırılmış görüşme formunun kullanıldığı çalışmada KKTC devlet ilkokullarında çalışan 13 sınıf öğretmeni ile görüşülmüş ve içerik analiziyle cevapları irdelenmiştir. Araştırma sonucuna göre öğrencilerin ağırlıklı olarak akademik başarısızlık, iletişim sorunları ve kültür farklılığı konularında sorunlar yaşadıkları belirlenmiştir.

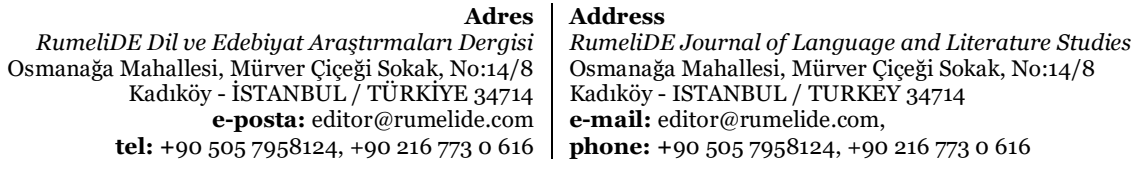


Miçooğulları (2020) çalışmasında KKTC MEKB Talim ve Terbiye Dairesi tarafından hazırlanan Yabancılara Yönelik Türkçe Destek Programlarını yaş seviyelerine göre karşılaştırarak değerlendirmiştir. Çalışmada tarama modeliyle incelenen programlar ilkokul (6-12 yaş) ve ortaokul-lise (13-17) başlangıç seviyesine hitap eden programlardır. Araştırmacıya göre, hazırlanan bu programlar, çeşitli ihtiyaç analizleri ile daha kapsamlı ve işlevsel bir duruma getirilmelidir.

Güntaş, Güneyli ve Gökbulut (2020) çalışmalarında, harmanlanmış öğrenmeye dayalı yabancı dil olarak Türkçe öğretiminde e-öğrenme ve öz-yeterlik düzeylerini değerlendirmeyi amaçlamışlar ve bu amaçla yarı deneysel modelde araştırmaya katılan 33 Türkçe öğretmen adayının hem özyeterlikleri hem de eöğrenme tutumlarını değerlendirmişlerdir. Değerlendirme sonucunda Türkçe öğretmen adaylarının eöğrenmeye yönelik deneysel uygulama sürecine ait olumsuz görüşleri arasında öğretmen etkisinin azalması, dersin yararlı/verimli olmaması, sosyalleşmenin sınırlı olması, akran ilişkilerinin olumsuz etkilenmesi, kalıcı öğrenmenin gerçekleşmemesi, dersin sıkıcı olması, motivasyonun düşmesi, akademik başarının olumsuz olması bulunmaktadır. Öğrencilerin bu konudaki olumlu görüşleri arasında ise; dersin faydalı/verimli olması, öğrencinin kendini iyi hissetmesi ve zamanını iyi kullanması gibi görüşler yer almaktadır.

Güntaş, Güneyli ve Gökbulut'un (2021) diğer çalışmasında, Türkçe öğretmeni adaylarının "Yabancı Dil Olarak Türkçe” dersine bağlı olarak uygulanan harmanlanmış öğrenmeye ilişkin, tutum ve görüşlerini belirlemeye çalışmışlardır. Öğretmen adaylarının deneysel uygulama sürecindeki olumlu görüşlerine bakıldığında, harmanlanmış öğrenmenin özellikle teknoloji kullanımı, ders içeriğinin erişilebilirliği, ders materyallerinin çeşitlendirilmesi ve maliyetin düşürülmesi üzerinde etkili olduğu konusunda fikir birliğinde bulundukları belirlenmiştir. Bunun yanında öğretmen adaylarının harmanlanmış öğrenmenin teknolojik altyapı ve donanım sorunları yaratabileceği ve öğretmenlerin bu yaklaşımı etkili bir şekilde kullanamayacağı yönünde görüş bildirdikleri ortaya çıkmıştır.

$\mathrm{Bu}$ alanda değerlendirilecek son iki çalışma da KKTC Milli Eğitim ve Kültür Bakanlığı (MEKB) (2020) tarafından hazırlanan "Yabancılara Yönelik Türkçe Destek Programı 6-12 Yaş Başlangıç Seviyesi" ve "Yabancılara Yönelik Türkçe Destek Programı 13-17 Yaş Başlangıç Seviyesi” adlı uyum ve destek programlarıdır. Her iki program da, Avrupa Dil Gelişim Dosyası temel alınarak hazırlanmış ve kazanımlar için Diller İçin Avrupa Ortak Başvuru Metni’nde tanımı yapılan yeterlikler göz önünde bulundurulmuştur. Komisyon tarafından hazırlanan program yapılandırılırken sarmal ve doğrusal programlama yaklaşımı kullanılmıştır. Bu programların ana amaçları hem öğrencilerin Türkçe dil becerilerini geliştirmek hem de Kıbrıs Türk toplumuyla uyum içinde olmalarını sağlayacak ülkenin kültürel özelliklerini onlara tanıtmaktır.

Alanyazın değerlendirildiğinde KKTC'de yabancı dil olarak Türkçe öğretimiyle ilgili gerek uygulama gerekse bilimsel çalışmaların sınırlı sayıda olduğu görülmektedir. Bu çalışmada KKTC'deki yabancı dil olarak Türkçe öğretiminin genel durumunu kapsamlı ve ayrıntılı bir şekilde ele alıp değerlendirmenin alanyazına katkı sağlayacağı düşünülmüştür.

\section{Yöntem}

$\mathrm{Bu}$ çalışmada nitel araştırma ve durum çalışması modeline uygun olarak veri toplanmıştır. Alanyazına bakıldığında durum çalışmasının sosyal bilimlerde sıklıkla tercih edildiği görülmektedir. Durum çalışması modeli; açıklayıcı özellikte, keşfe dönük ve tanımlayıcı özelliklere sahip bir araştırma modelidir (Baxter \& Jack, 2008). Bu çalışmada durum çalışmasının tercih edilme sebeplerinden biri,

\footnotetext{
Adres | Address

RumeliDE Dil ve Edebiyat Araştırmaları Dergisi $\quad$ RumeliDE Journal of Language and Literature Studies Osmanağa Mahallesi, Mürver Çiçeği Sokak, No:14/8 $\quad$ Osmanağa Mahallesi, Mürver Çiçeği Sokak, No:14/8 Kadıköy - ISTANBUL / TURKIYE 34714 Kadıköy - ISTANBUL / TURKEY 34714 e-posta: editor@rumelide.com e-mail: editor@rumelide.com, tel: +90 505 7958124, +90 2167730616 phone: +90 505 7958124, +90 2167730616
} 
Teaching Turkish as a foreign language in Cyprus through the view of Turkish teacher candidates / S. Güntaş; A. Güneyli; B. Gökbulut (pp. 1-21)

çalışılacak konu hakkında araştırma durumu ya da ortamına ilişkin kapsamlı ve ayrıntılı bilgi edinme amacıdır. Durum çalışmaları, herhangi bir olayı ya da durumu yerinde inceleyebilme olanağı sunarken aynı zamanda olayın yaşandığı ortamda gerçek sonuçlara ulaşma ve bu sonuçları doğru şekilde analiz etme imkânı da sunmaktadır (Aytaçlı, 2012).

Araştırmada durum çalışması alt modellerinden biri olan bütüncül tek durum deseni temel alınmıştır. Araştırmada incelenen durum veya ortam tektir ve Kıbrıs olarak belirlenmiştir. Araştırmanın analiz birimi ise yabancı dil olarak Türkçe öğretimidir; dolayısıyla tek analiz birimi temel alındığından araştırmanın bütüncül özellikte olduğu söylenmelidir.

\section{1. Çalışma grubu}

Araştırmacılardan biri, kolay ulaşılabilir durum örneklemine uygun olarak kendi öğrenim gördüğü üniversitede ve danışmanının görev yaptığı fakültede hızlı, erişimi kolay ve ekonomiklik gibi faktörleri göz önünde bulundurarak çalışmaya yönelmiştir.

Bu çalışmaya katılan Türkçe öğretmen adayları, kolay ulaşılabilir durum örneklemesi temel alınarak belirlenmiştir. Araştırmada, Türkçe Öğretmenliği bölümünde öğrenim gören üçüncü sınıf öğrencileri ile çalışılmıştır. Buna ek olarak çalışmada ölçüt örneklemesi de temel alınmıştır. Ölçüt örnekleme, herhangi bir örneklemin belli sinırlar ve koşullar temelinde belirlenmesiyle ilgilidir (Büyüköztürk ve diğerleri, 2012). Çalışmaya katılan Türkçe öğretmen adaylarının gelişim psikolojisi, öğretim ilke ve yöntemleri ve özel öğretim yöntemleri gibi dersleri almış olmaları bir ölçüt olarak kabul edilmiştir. Yabancı dil olarak Türkçe öğretiminde bu derslerden edinilen bilgilerin kullanılmasının önemli olduğu gerçeğinden hareket edilmiştir.

Özetle, araştırmanın örneklem grubunu Yakın Doğu Üniversitesi Atatürk Eğitim Fakültesi Türkçe Öğretmenliği Ana Bilim Dalında 2017-2018 ylları arasında öğrenim gören öğrenciler oluşturmaktadır. Yükseköğretim sürecine devam eden ve üçüncü sınıfta öğrenim gören Türkçe öğretmeni adayları araştırmaya dâhil edilmiştir. Çalışma, 33 Türkçe öğretmen adayı ile yürütülmüştür. Bu öğretmen adaylarından 18’i kız, 15’i erkektir.

\subsection{Veri toplama aracı}

Araştırmada veri toplama aracı olarak açık uçlu sorularla hazırlanmış yarı yapılandırılmış görüş formu kullanılmıştır. Görüş formu hazırlanırken; alanyazın taranmış, alan uzmanlarının görüşleri alınmış ve pilot uygulama gerçekleştirilmiştir. Buna göre sorular aşağıdaki gibi belirlenmiştir:

- Yabancı dil olarak Türkçe eğitimi gerçekleştiren öğretmenlerin sahip olması gereken yeterlilik/beceri/bilgi düzeyi nasıl olmalıdır? Ana dili olarak Türkçe öğretenlerden farklı olarak hangi/becerilere sahip olmalıdır?

- Yabancı dil olarak Türkçe eğitiminde amaç-kazanımlar sizce neler olmalıdır?

- Türkçenin ana dili olarak öğretimi ile yabancı dil olarak öğretimi arasında öğrenme-öğretme sürecinde ne gibi benzerlikler vardır?

- Türkçenin ana dili olarak öğretimi ile yabancı dil olarak öğretimi arasında öğrenme-öğretme sürecinde ne gibi farklılıklar vardır?

\footnotetext{
Adres $\mid$ Address

RumeliDE Dil ve Edebiyat Araştırmaları Dergisi $\quad$ RumeliDE Journal of Language and Literature Studies

Osmanağa Mahallesi, Mürver Çiçeği Sokkak, No:14/8 $\quad$ Osmanağa Mahallesi, Mürver Çiçeği Sokak, No:14/8

Kadıköy - ÍSTANBUL / TÜRKIYE 34714 Kadıköy - ISTANBUL / TURKEY 34714

e-posta: editor@rumelide.com e-mail: editor@rumelide.com,

tel: +90 505 7958124, +90 2167730616 phone: +90 505 7958124, +90 2167730616
} 
- Türkçenin yabancı dil olarak öğretiminde ne tür yöntem-teknik-strateji ve araç gereç kullanılmalıdır?

- Türkçeyi yabacı dil olarak öğrenen öğrencilerin kaygılarını azaltma ve Türkçeyi/ Türk kültürünü sevdirmek için motivasyon düzeyini arttırmaya yönelik neler yapılabilir?

- Türkçeyi yabancı dil olarak öğrenen öğrencilerin yaşadıkları sorunlar sizce nelerdir? Sorunların nedenleri ne olabilir ve bu sorunlara yönelik çözüm önerileri nelerdir?

Yukarıdaki sorulara ilişkin görüşlerini netleştirebilmek için Türkçe öğretmen adaylarının 3 ay süresince Kıbrıs'ta ortaöğretim okullarında gözlem yapmaları, öğretmenlerle görüşleri, konuyla ilgili web sitelerini incelemeleri, makaleler okuyup değerlendirmeleri ve "Yabancı Dil Olarak Türkçe Öğretimi" dersindeki kazanım ve tartışmaları dikkate alarak yorum yapmaları istenmiştir.

\subsection{Verilerin toplanması}

Araştırmanın verilerini elde etmek için Yakın Doğu Üniversitesi Bilimsel Araştırmalar Etik Kurulu gerekli izin alınmıştır. Araştırma verilerini toplamak amacıyla araştırmacılardan biri Türkçe öğretmen adaylarıyla bire bir ve yüz yüze görüşmeler gerçekleştirmiştir. Katılımcıların bu araştırmada yer alması tamamen gönüllülük esasına dayandırılmış, onlara isimlerinin araştırmada açıkça kullanılmayacağı ve araştırmanın gizlilik esasına uygun olarak yürütüleceği belirtilmiştir. Katılımcılar, kendilerinden toplanan görüşlerin araştırmacılar tarafından bilimsel araştırmalar dışında kullanılmayacağı konusunda bilgilendirilmişlerdir.

\subsection{Verilerin analizi}

Nitel veri analizinde içerik analizi gerçekleştirilmiş, temalar ve alt temalar oluşturulmuş, veriler tablolaştırılıp frekansları sunulmuş ve öğretmen adaylarının görüşlerinden doğrudan alıntılar yapılmıştır (Creswell \& Clark, 2017). Öğretmen adaylarının görüşleri, ÖA1, ÖA2 şeklinde kodlanarak verilmiştir.

Nitel veri analizinde geçerlik ve güvenirlik için aşağıdaki açıklamalar dikkate alınmıştır.

Geçerlik: Verilerin detaylı olarak yazılıp sonuçlarının açık ve anlaşılır şekilde ifade edilmesidir. Öğretmen adaylarının görüşleri alınmış, elde edilen sonuçlar bu görüşlerden yola çıkılarak belirtilmiştir. Araştırmanın bulgular kısmına bakıldığında kendi içerisinde tutarlılık ve anlamlılık söz konusudur. Belirtilen kavramların bir bütün oluşturacak nitelikte olduğu söylenebilir. Bu çalışmayı gerçekleştiren araştırmacılar, devamlı olarak hem kendilerini hem de araştırma sürecini eleştirel bakış açısı ile değerlendirmişlerdir. Bulgulardan elde edilen sonuçların gerçeği ne derece yansıtıp yansıtmadığını kontrol etmişlerdir (Yıldırım \& Şimşek, 2005). Araştırmanın elde edilen sonuçlar ile bu araştırmayı oluşturan araştırma soruları arasında tutarlılık olduğu söylenebilir. Araştırma bulgularından hareketle başka araştırmalarda sinanma amacıyla gerekli açlklamalara yer verildiği görülmektedir. Araştırmacılar, elde ettikleri sonuçlar ile benzer ortamlara yönelik genelleme yapabilmenin söz konusu olabileceğini ifade ederken aynı zamanda araştırmanın her aşaması hakkında detaylı bilgilendirme yapmışlardır (Yıldırım \& Şimşek, 2005). Kapsam geçerliği için uzman görüşlerine başvurulmuş, üç Türkçe eğitimi alan uzmanının görüşleri temelinde görüş formu biçimlendirilmiştir.

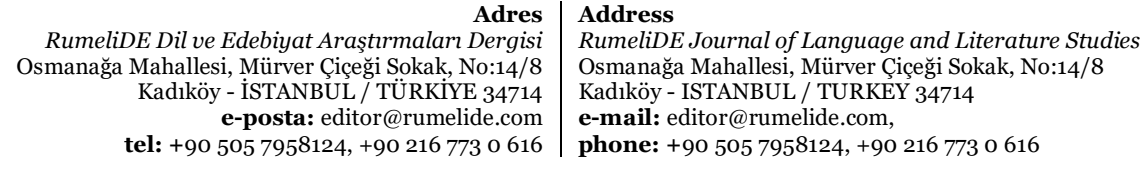


Teaching Turkish as a foreign language in Cyprus through the view of Turkish teacher candidates / S. Güntaş; A. Güneyli; B. Gökbulut (pp. 1-21)

Güvenirlik: Çalışmanın her adımına araştırmacılar beraber karar vermiştir. Örnek vermek gerekirse; çalışma sorularının oluşturulmasında özellikle nelere dikkat edilmesi gerektiği, görüşme gerçekleştirilirken nelerin önemli olduğu birlikte düşünülmüş, tartışılmış ve karar verilmiştir. Yine yapılan pilot çalışma (ön uygulama), görüşmeler, verilerin çözümlenmesi, yorumlanması ve karşılaştırılması beraber gerçekleştirilmiştir. Dış güvenirliği sağlamak için verilerin kaynağını oluşturan öğretmen adayları açı bir biçimde tanımlanmıştır. Bu şekilde bu çalışmaya benzer araştırma yapmak isteyen araştırmacılar, örneklemi seçerken dikkat edilmesi gerekenler hakkında bilgi sahibi olabilirler. Son olarak gerekli durumlarda başkaları tarafından incelenmesi için veriler titizlikle gizlenmiş ve veriler çözümlenirken içerik analizi sürecinde kodlayıcılar arası tutarlığın \%70 ve üzerinde olmasına dikkat edilmiştir. Araştırma sorularından biri olan ana dili olarak Türkçe öğretimi ile yabancı dil olarak Türkçe öğretiminin farklılığına ilişkin soru araştırmadaki iki kodlayıcı tarafından birlikte çözümlenmiş ve toplam 49 kod ortaya konmuştur. Daha sonra kodlayıcılar ayrı çalışarak tema adlarına karar vermişlerdir. 49 kodun 38 'inde iki kodlayıcı görüss birliğine vararak tema isimlerini belirlemiştir. Bu durumda uyumun \%77.5 olduğu görülmüştür.

\section{Bulgular}

Araştırma soruları temelinde içerik analizi gerçekleştirilmiş ve bulgular tablolaştırılarak aşağıda sunulmuştur.

Tablo 1. Yabancı dil olarak Türkçe öğreten eğitimcilerin mesleki ve alan yeterliliklerine ilişkin öğretmen adaylarının görüşleri

\begin{tabular}{|c|c|c|c|c|}
\hline Tema & \multicolumn{2}{|l|}{ Alt Temalar } & $\mathbf{N}$ & Toplam \\
\hline & \multicolumn{2}{|c|}{ Materyaller kullanmalı } & 6 & \\
\hline & \multicolumn{2}{|c|}{ Öğrencilere firsat vermeli } & 4 & \\
\hline & \multicolumn{2}{|c|}{ Bilgiyi tek bir şekilde değil, görsel-işitsel yoldan vermeli } & 4 & \\
\hline & \multicolumn{2}{|c|}{ Konuya hâkim olmalı ve derse hazırlıklı gelmeli } & 3 & \\
\hline & \multicolumn{2}{|c|}{ Mesleğinin gereklerini iyi bilmeli } & 3 & \\
\hline & \multicolumn{2}{|c|}{ Öğrencileri iyi yetiştirmek için uğraşmalı } & 3 & 36 \\
\hline & \multicolumn{2}{|c|}{ Mesleğinde iyi bir model olmalı } & 2 & \\
\hline & \multicolumn{2}{|c|}{ Sabırlı olmalı ve dersi eğlenceli anlatmalı } & 2 & \\
\hline Öğretme becerisi (mesleki & \multicolumn{2}{|c|}{ Farklı türden etkinliklerle öğretim yapmalı } & 2 & \\
\hline yeterlik) iyi olmalı & \multicolumn{2}{|c|}{ Yeniliklere açık olmalı } & 2 & \\
\hline & \multicolumn{2}{|c|}{ Bir sözcüğü farklı şekillerde anlatabilmeli } & 1 & \\
\hline & \multicolumn{2}{|c|}{ Öğreteceği konuda bilgi birikimi olmalı } & 1 & \\
\hline & \multicolumn{2}{|c|}{ Bildiklerini aktarabilme konusunda başarılı olmalı } & 1 & \\
\hline & \multicolumn{2}{|c|}{ İçeriğe hâkim olmalı } & 1 & \\
\hline & \multicolumn{2}{|c|}{ Jest ve mimiklerini etkili kullanabilmeli } & 1 & \\
\hline & \multicolumn{2}{|c|}{ Etkileyici olmalı } & 6 & \\
\hline & \multicolumn{2}{|c|}{ Otoritesini kullanabilmeli } & 5 & \\
\hline & \multicolumn{2}{|c|}{ Sabırlı olmalı empati duygusu yüksek olmalı } & 3 & \\
\hline Olumlu kişilik özelliklerine & \multicolumn{2}{|c|}{ Öğrencileri sevmeli } & 3 & \\
\hline sahip olmalı & \multicolumn{2}{|c|}{ Sabırlı olmalı } & 3 & \\
\hline & \multicolumn{2}{|c|}{ Zorlukların üstesinden gelebilecek bir yapıda olmalı } & 2 & $\mathbf{2 8}$ \\
\hline & \multicolumn{2}{|c|}{ İnsanlarla iyi anlaşabilmeli } & 2 & \\
\hline & \multicolumn{2}{|c|}{ Kendine güveni olmalı } & 1 & \\
\hline & \multicolumn{2}{|c|}{ Özgüven eksikliği olmamalı } & 1 & \\
\hline & \multicolumn{2}{|c|}{ Güler yüzlü olmalı } & 1 & \\
\hline $\begin{array}{r}\text { RumeliDE Dil ve Edel } \\
\text { Osmanağa Mahallesi, Mi } \\
\text { Kadıköy - ÍS } \\
\text { e-pc } \\
\text { tel: +90 } 505\end{array}$ & $\begin{array}{r}\text { Adres } \\
\text { Araştırmaları Dergisi } \\
\text { Chiçeği Sokak, No:14/8 } \\
\text { BUL / TÜRKiYE } 34714 \\
\text { editor@rumelide.com } \\
124,+902167730616\end{array}$ & $\begin{array}{l}\text { Address } \\
\text { RumeliDE Journal of Language and Literatur } \\
\text { Osmanağa Mahallesi, Mürver Çiçeği Sokak, No } \\
\text { Kadıöy - ISTANBUL / TURKEY } 34714 \\
\text { e-mail: editor@rumelide.com, } \\
\text { phone: +90 505 7958124, +90 } 216773 \text { o } 616\end{array}$ & $\begin{array}{l}\text { Idies } \\
8\end{array}$ & \\
\hline
\end{tabular}




\begin{tabular}{|c|c|c|c|}
\hline & Kendini geliştirmeli & 1 & \\
\hline \multirow{4}{*}{$\begin{array}{l}\text { Yabanci dil bilmeli ve } \\
\text { kullanabilmeli }\end{array}$} & Yabancı dile hâkim olmalı & 11 & \multirow{4}{*}{24} \\
\hline & Yabancı dil bilgisine sahip olmalı & 9 & \\
\hline & Hem kendi dilinin hem de diğer dilin özelliklerini bilmeli & 2 & \\
\hline & $\begin{array}{l}\text { Yabancı dili kullanarak öğrencilerine en iyi şekilde } \\
\text { anlatım yapabilmeli }\end{array}$ & 2 & \\
\hline \multirow{6}{*}{$\begin{array}{l}\text { Konuşma- kendini ifade etme } \\
\text { becerisi ile telaffuzu iyi } \\
\text { olmalı ve beden dilini etkili } \\
\text { kullanmalı }\end{array}$} & Anlatım gücü etkili olmalı & 5 & \multirow{6}{*}{14} \\
\hline & Gereksiz sözcükten kaçınmalı & 3 & \\
\hline & Kendini iyi ifade etmeli & 3 & \\
\hline & Sözcüklerin telaffuzuna dikkat etmeli & 1 & \\
\hline & İyi bir diksiyona sahip olmalı & 1 & \\
\hline & Jest ve mimikleri doğru kullanmalı & 1 & \\
\hline \multirow{3}{*}{$\begin{array}{l}\text { Türkçe dil bilgisi kurallarına } \\
\text { hâkim olmalı }\end{array}$} & Dilbilgisi kurallarını bilmeli & 5 & \multirow{3}{*}{12} \\
\hline & Dilbilgisine hâkim olmalı & 4 & \\
\hline & Anadilinin kurallarını ve güzelliklerini iyi bilmeli & 3 & \\
\hline \multirow{3}{*}{$\begin{array}{l}\text { Yabancı dil öğretiminin } \\
\text { eğitimini almalı ve öğretme } \\
\text { belgesi olmalı }\end{array}$} & Dil öğretim belgesi olmalı & 2 & \multirow{3}{*}{6} \\
\hline & Yabancılara Türkçe öğretimi dersini almış olmalı & 2 & \\
\hline & Yabancılara Türkçe öğretiminde deneyim sahibi olmalı & 2 & \\
\hline
\end{tabular}

Tablo 1 incelendiğinde Türkçe öğretmen adaylarının özellikle öğretme becerisinin (mesleki yeterlilik) iyi olması (n=36) konusuna vurgu yaptıkları görülmüştür. Bu konudaki öğretmen adaylarının görüşleri şöyledir: "Öğretmen konuya her zaman hâkim olmalı ve hazırlıkh gelmelidir. Alan bilgisi yeterli olmahdır. Mesleğinin gereğini iyi bilmesi gerekmektedir. Sabırh olmahdır. Öğrencileri sevmeli, onları yetiştirmek için uğraşmahdır.” (ÖA8). Diğer iki görüş ise şöyledir: “İyi bir diksiyona sahip olmalıdır. Kendine yeterince güvenmelidir. İnsanlarla iyi anlaşabilmelidir. Öğreteceği dilin özelliklerini ve ayrıntılarımı iyi bilmelidir. Konuştuğu dile hâkim olmahdır ve farkh etkinliklerle uğ raşmayı öğretmeyi sevmelidir. Yeniliklere açı olmahdır." (ÖA11). "Öğreten kişinin bilgi birikimi olması gerekir. Ayrıca bu bilgileri karşısındaki kişiye iyi bir şekilde aktarması gerekir. Uygulayacağı öğretim şekli, stratejiler önemlidir.” (ÖA13).

Bu tabloda ortaya çıkan ikinci temada ise Türkçe öğretmen adayları yabancı dil olarak Türkçe öğretecek eğitimcilerin olumlu kişilik özelliklerine $(\mathrm{n}=28)$ sahip olmasına vurgu yapmışlardır. Bu temaya ilişkin Türkçe öğretmen adaylarının görüşleri şöyledir: "Sabırl olmah. Empati duygusu yüksek olmahdır. Öğrenci ile arkadaş olabilmeli...” (ÖA4). Bir diğer görüş, "Yaratıcı olmahdır. Kendine güveni olmahdır.”(ÖA12). Başka bir öğretmenin görüşü ise "Özgüven eksikliği olmamahdrr. Sabırl, sıcakkanl ve güler yüzlü olmahdır.” (ÖA17) şeklinde olmuştur.

Araştırmada yabancı dil olarak Türkçe öğretecek öğretmenlerin yabancı dil bilmesi ve kullanabilmesinin (n=24) önemli olduğu görüşü de ortaya çımıştır. Öğretmen adaylarının görüşleri şöyledir: "Etkinlikler yapması önemlidir. Yabancı dile hâkim olmalıdır." (ÖA7). "Türkçe öğreten kişilerin yabancı dili en yüksek seviyede olmahdır. Böylelikle karşısındakine en iyi şekilde her şeyi anlatabilir.” (ÖA15).

Türkçe öğretmen adaylarının; yabancı dil olarak Türkçe öğretecek eğitmenlerin konuşma, kendini ifade etme becerisi ile telaffuzunun iyi olması ve beden dilini etkili kullanması $(n=14)$ konularında da görüş

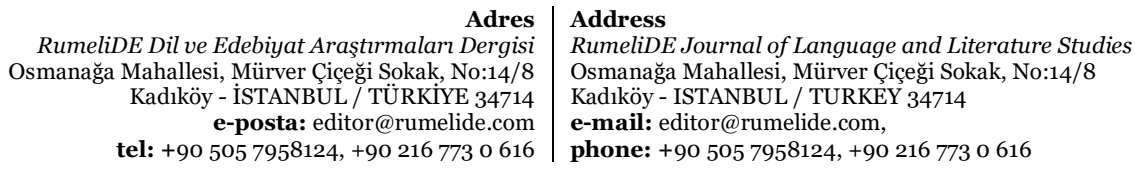


Teaching Turkish as a foreign language in Cyprus through the view of Turkish teacher candidates / S. Güntaş; A. Güneyli; B. Gökbulut (pp. 1-21)

belirttikleri görülmüştür. Bu konuya ilişkin bir öğretmen adayı, "İyi bir diksiyona sahip olmahdrr. Kendine yeterince güvenmelidir. İnsanlarla iyi anlaşabilmelidir. Öğreteceği dilin özelliklerini ve ayrıntılarını iyi bilmelidir. Konuştuğu dile hâkim olmahdır ve farkl etkinliklerle uğraşmayı öğretmeyi seumelidir. Yeniliklere açı olmahdır." (ÖA11) demiştir.

Bir diğer temada yabancı dil olarak Türkçe öğretecek eğitimcilerin Türkçe dilbilgisi kurallarına hâkim olması (n=12) konusuna vurgu yapılmıştır. Bu konuda öğretmen adaylarından biri "Anadilinin tüm özelliklerini bilmelidir. Dilbilgisi kurallarm bilmelidir. Anlatım gücü etkili olmahdır. Etkileyici olmahdır. Gereksiz sözcükten kaçınmalıdır." (ÖA1) demiştir. Bir diğer öğretmen adayı ise "Dilbilgisine hâkim bir öğretmen olması gerekiyor." (ÖA10) şeklinde yorum yapmıştır.

Öğretmen adayları bu soruya ilişkin son olarak yabancı dil olarak Türkçe öğretecek eğitimcilerin yabancı dil öğretimi eğitimini almış ve belgesi olmalı $(n=4)$ konularına ilişkin görüş bildirdikleri görülmüştür. İki öğretmen adayının görüşü şöyledir: "Yabancı dil eğitimi alanında belgesi olmalıdır." (ÖA3). Diğer bir öğretmen adayı ise, "Bu ders için eğitim almış olması gerekir.” demiştir. (ÖA5).

Tablo 2. Yabancı dil olarak Türkçe öğretiminde kazanımlara ilişkin öğretmen adaylarının görüşleri

\begin{tabular}{|c|c|c|c|}
\hline Tema & Alt Temalar & $\mathbf{N}$ & Toplam \\
\hline \multirow{6}{*}{$\begin{array}{l}\text { Öğrenciye yönelik } \\
\text { kazanımlar }\end{array}$} & Türkçeyi güzel ve akıcı konuşmak & 11 & \multirow{6}{*}{26} \\
\hline & Türkçeyi günlük hayatta etkili kullanabilme & 8 & \\
\hline & Türkçe anlama becerilerini geliştirme & 3 & \\
\hline & Yabancı dilden arındırılmış cümleler kurabilme & 2 & \\
\hline & Dilbilgisi kurallarını öğrenme & 1 & \\
\hline & Sözcük dağarcığını geliştirme & 1 & \\
\hline \multirow{5}{*}{$\begin{array}{l}\text { Ö̈̆gretmene yönelik } \\
\text { kazanımlar }\end{array}$} & Türkçeyi dilbilgisi kurallarına önem vererek öğretme & 15 & \multirow{5}{*}{35} \\
\hline & $\begin{array}{l}\text { Türkçeyi öğretirken etkili yöntem ve teknikleri } \\
\text { kullanabilme }\end{array}$ & 9 & \\
\hline & $\begin{array}{l}\text { Türkçeyi dünya dili haline getirme ve farklı toplumlar } \\
\text { tarafindan kullanılmasını sağlamak }\end{array}$ & \multirow{3}{*}{$\begin{array}{l}5 \\
4 \\
2\end{array}$} & \\
\hline & Türkçeyi sevdirme & & \\
\hline & İyi bir konuşmacı yetiştirmek & & \\
\hline Bilgim yok & - & 6 & 6 \\
\hline
\end{tabular}

Tablo 2 incelendiğinde Türkçe öğretmen adaylarının yabancı dil olarak Türkçe öğretiminde öğrenciye yönelik kazanımlar konusuna ( $\mathrm{n=26}$ ) vurgu yaptıkları görülmüştür. Bu temayla ilgili bazı öğretmen adaylarının görüşleri şöyledir:

“Öğrencilerin Türkçeyi doğru, etkili, güzel bir şekilde konuşmalarmı sağlamak.”(ÖA8)

“Türkçeyi anlama ve konuşma çok önemlidir.”(ÖA13)

"Yabancı sözcüklerden arındırlmış cümleler kurabilmelidirler.”(ÖA13)

"Kelime haznesinin gelişmiş olmasını isterim.” (ÖA1)

Yabancı dil olarak Türkçe öğretiminde öğretmene yönelik kazanımlar ( $n=35)$ konusuna da bu araştırmacının katılımcıları değinmişlerdir.

“Türkçeyi doğru bir şekilde aktarmanın yöntem ve tekniklerini göstermek...”(ÖA9)

“Türkçemizi geniş alanlara yaymak ve farkl kültürlerle iç içe olmak için çaba harcamak...”(ÖA22)

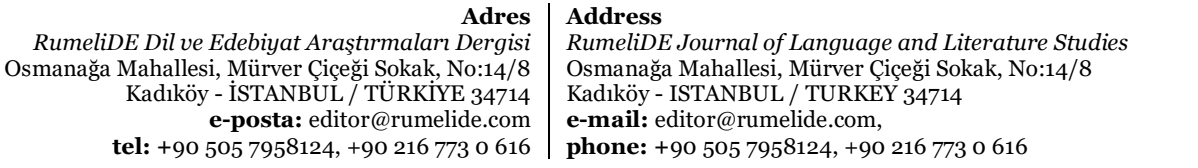


Türkçe öğretmen adaylarının gözünden Kıbrıs’ta yabancı dil olarak Türkçe öğretimi / S. Güntaş; A. Güneyli; B. Gökbulut (pp. 121)

“Türkçeyi sevdirmek.”(ÖA6)

“İyi bir konuşmacl yetiştirmek.”(ÖA17)

Tablo 3. Yabancı dil olarak Türkçe öğretiminde içeriğe ilişkin öğretmen adaylarının görüşleri

\begin{tabular}{lc}
\hline Tema & Toplam \\
\hline Günlük yaşam ve diyaloglar & 10 \\
Dil becerilerini geliştirmeye yönelik metinler & 7 \\
Dilbilgisi kurallarını kazandırmaya yönelik metinler & 5 \\
Sözcük dağarcığını (atasözleri vb.) geliştirmeye yönelik metinler & 4 \\
Türk kültürü & 4 \\
Atatürk & 2 \\
Türk milliyetçiliği & 2 \\
Gençlik & 1 \\
Atalarımız & 1 \\
Doğa ve Evren & 1 \\
Türkiye coğrafyası & 1 \\
\hline
\end{tabular}

Tablo 3 incelendiğinde yabancı dil olarak Türkçe öğretiminde içerik konusunda aşağıdaki başlıklara vurgu yapıldığı görülmüştür. Günlük yaşam ve diyaloglar kurma, Türk kültürü, Atatürk, Türk milliyetçiliği, gençlik, atalarımız, doğa ve evren ve son olarak da Türkiye coğrafyası. Bu başlıklarla ilgili bazı öğretmen adaylarının görüşleri şöyledir:

“Türk kültürüne ait konular olmahdır. Kültürümüzü öğrenirlerse kelimeleri anlamaları kolaylaşır.” (ÖA1)

“Atatürk, atalarmmza yer verilmelidir.”(ÖA4)

“Doğa, evren, Türkiye gibi metinlere yer verilmelidir.” (ÖA7)

“Türkiye’nin kültürel özelliklerine, yemek kültürüne ait metinler kullanlabilir.”(ÖA25)

Tablo 4. Yabancı dil olarak Türkçe öğretiminde strateji-yöntem-teknik-araç kullanımına ilişkin öğretmen adaylarının görüşleri

\begin{tabular}{|c|c|c|c|c|}
\hline Tema & \multicolumn{2}{|l|}{ Alt Temalar } & $\mathbf{N}$ & Toplam \\
\hline \multirow[t]{3}{*}{ Strateji } & \multicolumn{2}{|l|}{ Sunuş } & 7 & \\
\hline & \multicolumn{2}{|c|}{ Buluş (yaparak-yaşayarak) } & 3 & 11 \\
\hline & \multicolumn{2}{|l|}{ Araştırma-inceleme } & 1 & \\
\hline \multirow[t]{6}{*}{ Yöntem-teknik } & \multicolumn{2}{|l|}{ Drama(rol oynama) } & 7 & \\
\hline & \multicolumn{2}{|l|}{ Oyun } & 4 & \\
\hline & \multicolumn{2}{|c|}{ Gösterip yaptırma } & 2 & 16 \\
\hline & \multicolumn{2}{|c|}{ Bireyselleştirilmiş eğitim } & 1 & \\
\hline & \multicolumn{2}{|c|}{ Tartışma } & 1 & \\
\hline & \multicolumn{2}{|l|}{ Proje } & 1 & \\
\hline \multirow[t]{8}{*}{ Araç-gereç } & \multicolumn{2}{|c|}{ Bilgisayar, projeksiyon ve slayt } & 21 & \\
\hline & \multicolumn{2}{|c|}{ Görseller (karikatür-resim-afiş-tablo) } & 14 & \\
\hline & \multicolumn{2}{|c|}{ İşitsel materyaller (ses kaydı, şarkı, cd ve müzik) } & 8 & \\
\hline & \multicolumn{2}{|c|}{ Video ve kısa film } & 7 & \\
\hline & \multicolumn{2}{|c|}{ Kitap-roman-gramer kitapları-çeviri eserler } & 6 & \\
\hline & \multicolumn{2}{|l|}{ Çalışma kâğıtları } & 2 & 62 \\
\hline & \multicolumn{2}{|l|}{ Sözlükler } & 2 & \\
\hline & \multicolumn{2}{|l|}{ Defter ve kalem } & 1 & \\
\hline $\begin{array}{r}R u \\
\text { Osma }\end{array}$ & $\begin{array}{r}\text { Adres } \\
\text { Araştırmaları Dergisi } \\
\text { Chiçeği Sokak, No:14/8 } \\
\text { BUL / TÜRKiYE 34714 } \\
\text { editor@rumelide.com } \\
124,+902167730616\end{array}$ & $\begin{array}{l}\text { Address } \\
\text { RumeliDE Journal of Language and } \\
\text { Osmanağa Mahallesi, Mürver Ciçeği S } \\
\text { Kadıköy - ISTANBUL / TURKEY } 3471 \\
\text { e-mail: editor@ @rumelide.com, } \\
\text { phone: +90 505 7958124, +90 216 77 }\end{array}$ & $\begin{array}{l}\text { udies } \\
8\end{array}$ & \\
\hline
\end{tabular}


Teaching Turkish as a foreign language in Cyprus through the view of Turkish teacher candidates / S. Güntaş; A. Güneyli; B. Gökbulut (pp. 1-21)

Tablo 4 incelendiğinde yabancı dil olarak Türkçe öğretiminde strateji (n=11) konusu ele alınmış ve sunuş, buluş(yaparak-yaşayarak) ve araştırma-inceleme başlıklarına yer verilmiştir. Bazı öğretmen adaylarının görüşleri şöyledir: "Sunum şeklinde teknolojik aletlerden faydalanarak uygulamaya dayah çalş̧malar yapılabilir." (ÖA4). "Yaparak-yaşayarak öğrenme." (ÖA14). "Dört temel dil becerilerimiz üzerinden gidilip dinleme-okuma-yazma-konuşmayı hedef alarak bunlarla ilgili etkinlikler düzenleyerek gidebilir." (ÖA14)

Yabancı dil olarak Türkçe öğretiminde yöntem-teknik (n=16) konusunda drama(rol oynama), oyun, gösterip yaptırma, bireyselleştirilmiş eğitim, tartışma ve proje gibi başlıklara yer verilmiştir. Bazı öğretmen adaylarının görüşleri şöyledir: "Uygun materyaller kullanıp öğretimde kolaylık sağlanabilir. Oyunlar yoluyla da olabilir." (ÖA7). "Teknoloji kullanlarak ve canlandirmalar yapılarak öğrencilere firsat verilmelidir. Gösterip-yaptırma yöntemi kullanılabilir." (ÖA13). "Bire bir eğitim, bilgisayar, çalışma kâğıtları, slaytlarla destek, video, ses kaydı vb. kullanılabilir.” (ÖA9).

Yabancı dil olarak Türkçe öğretiminde kullanılan araç-gereçler $(n=62)$ ise bilgisayar, projeksiyon ve slaytlar, görseller (karikatür-resim-afiş-tablo), işitsel materyaller (ses kaydı, şarkı, cd ve müzik), video ve kısa film, kitap-roman-gramer kitapları-çeviri eserler, çalışma kağıtları, sözlükler, defter ve kalem ve oyuncak olarak ifade edilmiştir. Bazı öğretmen adaylarının görüşleri şöyledir: "Teknolojik aletler, diyaloglar, sunumlar kullanılmalıdır." (ÖA2O). "Araç olarak slayt, bilgisayar, resim, karikatür kullanılabilir." (ÖA8). "Sesli dinleti, uygulamalar, tiyatro...” (ÖA19). "Şarkzlar, kısa filmler ve oyunlar yabancı dil eğitiminde kullanılabilir." (ÖA10). "Sözlükler, gramer kitapları, çeviri eserler kullanılmalıdır." (ÖA26). "Etkinlik kâ̆ğtları, görsel-işitsel materyaller vb. öğretimi olumlu yönde etkiler.” (ÖA16). “

Tablo 5. Yabancı Dil Olarak Türkçe Öğretiminin Ana Dili Öğretimiyle Benzerliğine İliş̧kin Öğretmen Adaylarının Görüşleri

\begin{tabular}{ll}
\hline Tema & N \\
\hline Dil bilgisi kuralları ve Türkçenin yapısı & 15 \\
Alfabe, ses ve harfler & 5 \\
Öğretim ilkeleri (basitten zora doğru öğretim) & 4 \\
Telaffuz & 4 \\
Öğretim amaçları (kazanımlar) & 4 \\
Öğretim yöntem-teknikleri & 3 \\
Bir benzerlik yok & 2 \\
Fikrim yok & 2 \\
Öğretilen temalar & 1 \\
\hline
\end{tabular}

Tablo 5 incelendiğinde yabancı dil olarak Türkçe öğretiminin benzerliğine ilişkin Türkçe öğretmen adaylarının farklı görüşlere vurgu yaptıkları görülmektedir. Aynı zamanda bir benzerlik olmadığını düşünen öğretmen adayları da olmuştur. Bazı öğretmen adaylarının görüşleri şöyledir:

"Dil bilgisi kuralları iki durumda da anlatılır."(ÖA5)

“İkisinde de temel kurallar var. Basitten zora doğru gidilmesi benziyor.”(ÖA4)

"Her ikisinde de amaç, karşımızdaki kişiye bilgi vermek, Türkçenin güzelliklerini öğretmektir.

Doğru telaffuzun nasıl elde edileceğ $i$, kelimelerin, cümlelerin yazımı vb.”(ÖA2O)

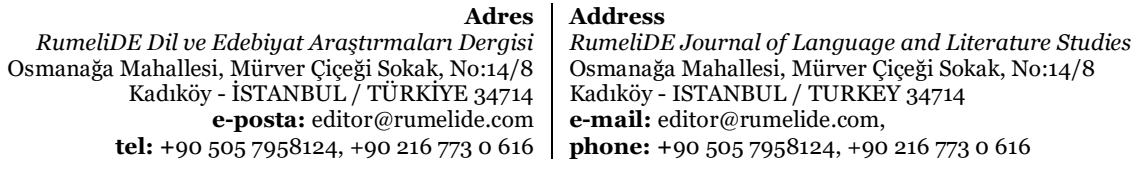


Türkçe öğretmen adaylarının gözünden Kıbrıs’ta yabancı dil olarak Türkçe öğretimi / S. Güntaş; A. Güneyli; B. Gökbulut (pp. 121)

"Bir benzerlik göremiyorum.”(ÖA7)

"Fikrim yok." (ÖA24)

Tablo 6. Yabancı dil olarak Türkçe öğretiminin ana dili öğretiminden farklılığına ilişkin öğretmen adaylarının görüşleri

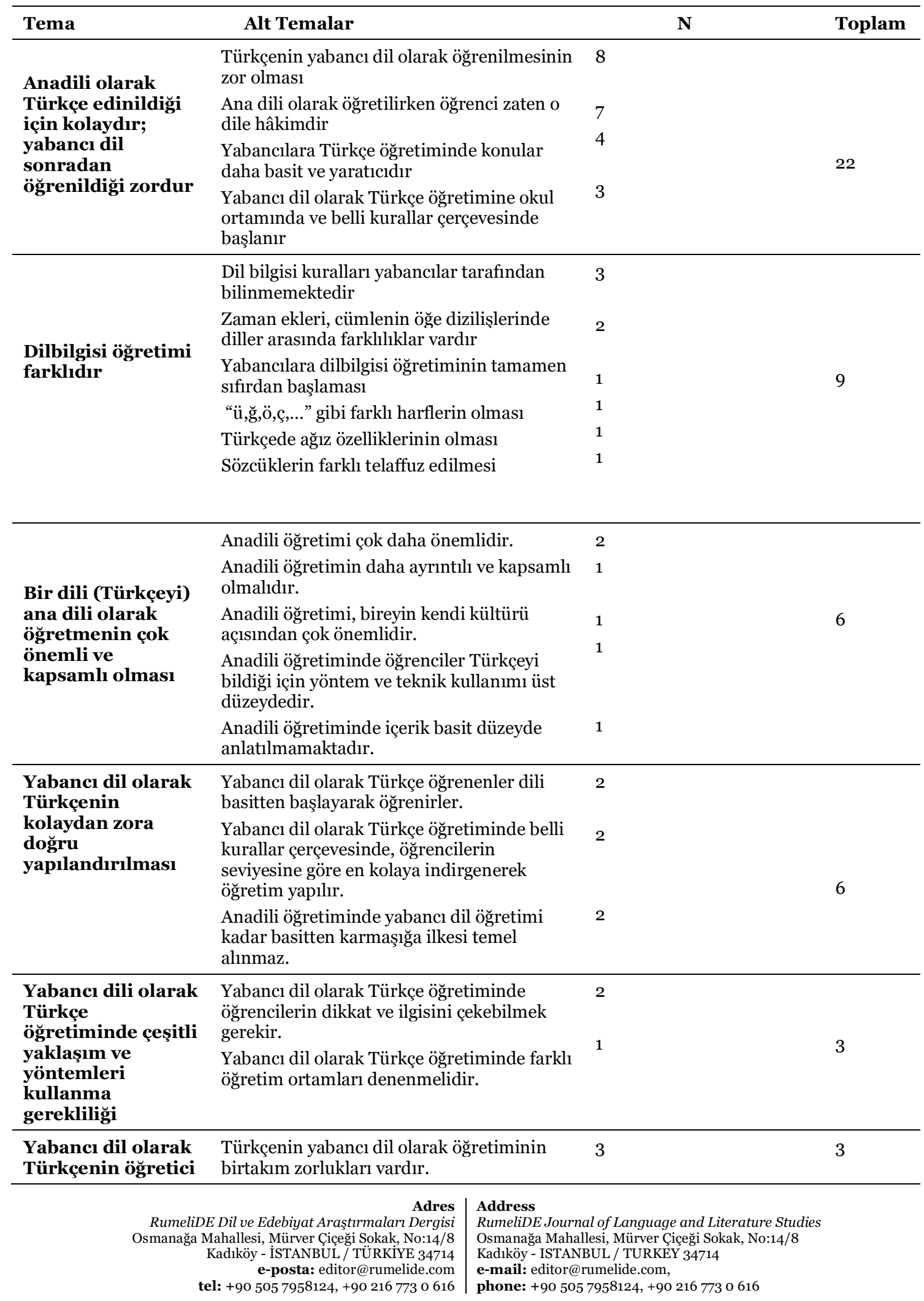


Tablo 6 incelendiğinde Türkçe öğretmen adaylarının özellikle ana dili olarak Türkçe edinildiği için kolaydır; yabancı dil sonradan öğrenildiği için zordur (n=22) konusuna vurgu yaptıkları görülmüştür. $\mathrm{Bu}$ konudaki görüşler şöyledir: "Türkçeyi anadili olarak öğrenenler zaten Türkçe konuşarak öğrendikleri için daha kolay öğrenirler ve bütün dilbilgisi, konuşma, yazma, okuma kurallarıyla öğrendikleri için daha ayrntılı dersler alırlar.” (ÖA6). Diğer bir görüş ise, “Ana dili olarak Türkçeyi çocuk aileden öğrenmeye başlar. İlk olarak çevreden duyduğu, yaşadiğı bölgeye ait olan dili öğrenir. Daha sonra okulda gördüğü eğitimle bunu destekler. Yabancı dil olarak Türkçe öğrenecek kişiler ise Türkçeyi öğrenmeye okul ortamında başlar. Belirli kurallar çerçevesinde Türkçeyi öğrenir." (ÖA12) şeklindedir.

Öğretmen adaylarına Türkçenin anadili ve yabancı dil olarak öğretimi arasındaki farklıklar sorulduğunda dilbilgisi öğretimini ön plana $(\mathrm{n}=9)$ çıkarmışlardır. Bir öğretmen adayının görüşü, "Dil bilgisi kuralları ve Türkçenin ağız özellikleri yabancllar tarafindan bilinmemektedir." (ÖA1) şeklinde olmuştur. Diğer bir öğretmen adayının görüşü, "Türkçede bulunan eklerin anlatımı, özellikle zaman eklerinin öğrenilmesi zordur ve cümlelerde öğelerin dizilişleri de farklıdır.” (ÖA2) şeklindedir. Bir diğer görüş ise, "Türkçedeki dilbilgisi kuralları ile yabancı dildeki kurallar birbirinden farkh olduğundan öğretme şekilleri farkhdır.” (ÖA3) olarak dile getirilmiştir.

Öğretmen adayları Türkçenin ana dili ve yabancı dil olarak öğretimi arasındaki farkları dile getirirken anadili olarak Türkçeyi öğrenme ve öğretmenin bir Türk için çok önemli ve kapsamlı olduğu üzerinde $(\mathrm{n}=6)$ durmuşlardır. Bir öğretmen adayı, "Anadilimiz daha önemlidir. Yabancı dil öğretimi daha yüzeysel geçilmektedir.” (ÖA8) demiştir. Diğer bir görüş, "Ana dili öğretiminde kişilere daha ayrntılı bilgiler öğretilmektedir. Ana dili bireyin kendi kültürü, konuşma dili olduğu için çok daha önemlidir.” (ÖA13) şeklinde olmuştur.

Türkçenin ana dili ve yabancı dil olarak öğretimi arasındaki diğer bir fark ise yabancı dil olarak Türkçe öğretiminin kolaydan zora doğru yapılandırılması konusudur $(\mathrm{n}=6)$. Öğretmen adaylarının görüşlerine bakıldığında; "Yabancı dil olarak Türkçeyi öğrenenler en basitten başlayarak öğrenirler." (ÖA6), "Türkçenin ana dili olarak öğretiminde yabancı dil kadar basitten karmaşı̆̆a gidildiğini düşünmüyorum." (ÖA16) ve "Türkçe öğretiminde karşımızdaki birey Türkçeyi bildiği için yöntem ve tekniğimizi ona göre ayarlarız. Konularımızı, basit düzeyde değil de orta düzeyde anlatabiliriz. Çünkü bireyin alt yapısı vardır. Ayrıca bireyin sadece hataların düzeltip yeni şeyler öğretiriz." (ÖA17) şeklindedir.

Öğretmen adayları yabancı dil olarak Türkçe öğretiminde çeşitli yaklaşım ve yöntemlerin kullanılma gerekliliğine $(\mathrm{n}=3)$ değinmişlerdir. Bir öğretmen adayının görüşü, "Yabancı dil olarak Türkçe öğretiminde öğrencilerin dikkatini, ilgisini çekecek derslere yönelmeliyiz.” (ÖA4) şeklinde olmuştur. Diğer bir öğretmen adayı ise, "Yabancı dil olarak Türkçe öğretiminde pek çok öğrenme ortamı ve platformundan yararlanılmahdır.” (ÖA7) demiştir.

Son olarak Türkçe öğretmen adayları yabancı dil olarak Türkçenin öğretici açısından daha zor olabileceğini $(\mathrm{n}=3)$ ortaya koymuşlardır. Bu konu ile ilgili bir öğretmen görüşü şöyledir: "Yabancı dil olarak öğretim sürecinde öğreten için zorluklar olabiliyor. Anadili öğretiminde dil küçüklükten öğrenildiği için ana dili daha iyi öğrenilir. Yabancı dil olarak öğrenim daha zordur.” (ÖA5)

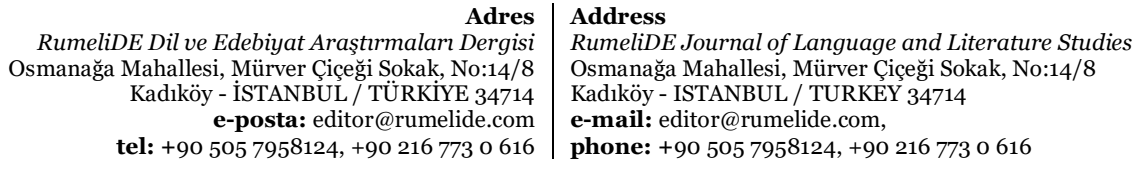


Türkçe öğretmen adaylarının gözünden Kıbrıs’ta yabancı dil olarak Türkçe öğretimi / S. Güntaş; A. Güneyli; B. Gökbulut (pp. 121)

Tablo 7. Yabancı Dil Olarak Türkçe Öğretiminde Öğrencileri Motive Etme ve Kaygılarını Azaltmaya Yönelik Öğretmen Adaylarının Görüşleri

\begin{tabular}{ll}
\hline Tema & $\mathbf{N}$ \\
\hline $\begin{array}{l}\text { Öğretim yöntem-teknikleri-materyalleri (gezi, drama, oyun, } \\
\text { film izletme) çeşitlendirme }\end{array}$ & $\mathbf{2 1}$ \\
\hline $\begin{array}{l}\text { Türk tarihi, coğrafyası ve kültürünü öğretip güzelliklere dikkat } \\
\text { çekme (yemekler-halk oyunları-müzikler-şiir-şarkı-bayram- } \\
\text { tarihi yerler) öğretme }\end{array}$ & $\mathbf{1 9}$ \\
\hline Türklerle vakit geçirecek ortamlar ve etkinlikler düzenleme & $\mathbf{9}$ \\
\hline Eğiticinin güler yüzlü, eğlenceli ve sabırlı olması & $\mathbf{5}$ \\
\hline $\begin{array}{l}\text { Öğretim ilkelerini etkili kullanma (kolaydan zora doğru Türkçe } \\
\text { ögretme }\end{array}$ & $\mathbf{2}$ \\
\hline Fikrim yok & $\mathbf{2}$ \\
\hline Sınavların ne çok zor ne de çok kolay olması & $\mathbf{1}$ \\
\hline Türkçeyi iyi konuşan yabancı kişileri örnek gösterme & $\mathbf{1}$ \\
\hline Nitelikli Türk edebi metinlerden yararlanma & $\mathbf{1}$ \\
\hline Öğrenme-öğretme ortamını elverişli hale getirme & $\mathbf{1}$ \\
\hline
\end{tabular}

Tablo 7 incelendiğinde yabancı dil olarak Türkçe öğretiminde öğrencileri motive etme ve kaygılarını azaltmaya yönelik öğretmen adaylarının 10 farklı görüş ortaya koydukları görülmüştür. Bazı görüşler şöyledir:

“Sunumlar yapılabilir, slaytlar kullanılabilir, filmler izletilebilir ve geziler düzenlenebilir.”(AÖ13)

“Onları gezdirerek Türkiye’nin özelliklerini, örf-adetlerini ve yemeklerini tanttı motivasyonlarmı arturabiliriz.”(ÖA8)

“Türk öğrencilerle veya vatandaşlarla birçok etkinliğe katılabilirler.”(ÖA3)

"Hoşgörülü ve sabırlı bir şekilde davranılması gerekir. Öğrencinin dili iyi öğrenebilmesi için çeşitli materyaller kullanılarak dersin eğlenceli hale gelmesi için çalş̧lmalıdır. Öğrenciyi derse güdülemek gerekir."(ÖA12)

“Türkçeyi iyi bir şekilde konuşan yabancı kişiler örnek gösterilebilir.”(ÖA20)

Tablo 8. Yabancı dil olarak Türkçe öğretimindeki sorunlara ve sorunların çözümüne ilişkin öğretmen adaylarının görüşleri

\begin{tabular}{|c|c|c|c|}
\hline Tema & Alt Temalar & $\mathbf{N}$ & Toplam \\
\hline \multirow{5}{*}{ Sorunlar } & Öğrenememe kaygısı ve motivasyon azlığı & 6 & \multirow{5}{*}{25} \\
\hline & Konuşma ve telaffuz sorunu & 4 & \\
\hline & Türkçenin zor bir dil olduğu düşüncesi & 4 & \\
\hline & Sözcük dağarcığının yetersizliği (çok anlamlılık) & 3 & \\
\hline & $\begin{array}{l}\text { Dilbilgisi kurallarını ve ekleri doğru } \\
\text { kullanamamak }\end{array}$ & 3 & \\
\hline
\end{tabular}

RumeliDE Dil ve Edebiyat Eeraşturmaları Dergisi Osmanağa Mahallesi, Mürver Çiçeği Sokak, No:14/8 Kadıköy - İSTANBUL / TÜRKIYE 34714 e-posta: editor@rumelide.com tel: +90 $5057958124,+902167730616$
Address

RumeliDE Journal of Language and Literature Studies

Osmanağa Mahallesi, Mürver Çiçeği Sokak, No:14/8

Kadıköy - ISTANBUL / TURKEY 34714

e-mail: editor@rumelide.com,

phone: +90 505 7958124, +90 2167730616 
Teaching Turkish as a foreign language in Cyprus through the view of Turkish teacher candidates / S. Güntaş; A. Güneyli; B. Gökbulut (pp. 1-21)

\begin{tabular}{|c|c|c|c|}
\hline & $\begin{array}{l}\text { Yabancı dil öğreten Türkçe eğitimcilerinin az } \\
\text { olması ve yeterli donanıma sahip olmamaları }\end{array}$ & 2 & \\
\hline & Harflerin yazımındaki sorunlar & $\mathbf{1}$ & \\
\hline & Kaynak ve materyal eksikliği & $\mathbf{1}$ & \\
\hline & Öğrencilerin hazırbulunuşluğunun tam olmaması & $\mathbf{1}$ & \\
\hline \multirow{9}{*}{$\begin{array}{l}\text { Çözüm } \\
\text { önerileri }\end{array}$} & Bol etkinlik ve uygulama yapma & 4 & \multirow{9}{*}{21} \\
\hline & Öğretimi basitleştirme & 4 & \\
\hline & $\begin{array}{l}\text { Öğrenci motivasyonunu artırma ve kaygısını } \\
\text { azaltma }\end{array}$ & 4 & \\
\hline & Sözlük çalışmaları & 2 & \\
\hline & Nitelikli dilbilgisi öğretimi & 2 & \\
\hline & Araştırmaya yönlendirme & $\mathbf{2}$ & \\
\hline & Öğretmenin güler yüzlü ve saygılı olması & $\mathbf{1}$ & \\
\hline & Türkçeyi sevdirme & $\mathbf{1}$ & \\
\hline & $\begin{array}{l}\text { Öğrencinin hazırbulunuşluğunu ve ön bilgilerini } \\
\text { kullanarak öğretim yapma }\end{array}$ & $\mathbf{1}$ & \\
\hline
\end{tabular}

Tablo 8 incelendiğinde yabancı dil olarak Türkçe öğretimindeki sorunlara (n=25) ilişkin öğretmen adaylarının görüşlerinin 9 başlıkta sıralandığı görülmüştür. Bu başlıklara ilişkin bazı görüşler aşağıdaki gibidir:

“Öğrenememe korkusu içinde olabilirler. Onları motive edecek unsurlardan yararlanırız.”(ÖA30)

“Konuşma ve telaffuzlarında zorluk ve sıkıntı çıkabilir.” (ÖA14)

"Sorunlar mecazlar olabilir. Bu sorunu izah ederek çözebiliriz”. (ÖA7)

“Dilbilgisi kurallarmda zorluk yaşayabilirler.” (ÖA5)

“Yeterli düzeyde eğitimci olmaması. Yeterli kaynak olmaması.”(ÖA13)

“Adapte olmakta zorlanırlar. Kaygı düzeyleri yüksek olur. Genellikle öğrenemem diye korkarlar. Ĕ̆itimciler güler yüzlü, saygılı olmalıdır.”(ÖA8)

Yabancı dil olarak Türkçe öğretimindeki yaşanan sorunlara yönelik öğretmen adaylarının çözüm önerileri ( $\mathrm{n}=21)$ ise 9 başlıkta tabloda sunulmuştur. Bu başlıklara ilişkin öğretmen adaylarının görüşleri şöyledir:

"Telaffuzda ve Türkçenin gramer yapısını anlamakta sorunları olabilir. Çünkü onlar için bambaşka bir dildir. Bu sorunların olması doğaldır. Dinleme becerisine yönelik bol etkinlik yapularak sorunlar giderilebilir." (ÖA28)

“Motivasyon eksikliği, çözümü ise ilgiyi arttırıcı sözler kullanmak.”(ÖA17)

"Kelime bilgileri olmaması, ekler sıkıntı olabilir. Bol bol sözlük çalışmaları ve gramer öğretimi yapılmalıdir.”(ÖA1)

"En büyük sorunlardan biri Türkçenin zor bir dil olduğunu düşünmeleri ve daha önce alt yapılarını olmamasından kaynaklıdır. Çözüm olarak ise öğretimde basitten zora gidilmesidir.” (ÖA16)

“Onları araştırmaya yönlendirmeli. Kütüphaneye göndermeli.”(ÖA6).

“Öğretmenlerin öğrencilere Türkçeyi sevdirmeleri gerekir.”(ÖA1o)

Adres
RumeliDE Dil ve Edebiyat Araştırmaları Dergisi
Osmanağa Mahallesi, Mürver Çiçeği Sokak, No:14/8
Kadıköy - İSTANBUL / TÜRKIYE 34714
e-posta: editor@rumelide.com
tel: +90 505 7958124, +90 2167730616
Address

RumeliDE Journal of Language and Literature Studies

Osmanağa Mahallesi, Mürver Çiçeği Sokak, No:14/8

Kadıköy - ISTANBUL / TURKEY 34714

e-mail: editor@rumelide.com,

phone: +90 5057958124, +90 2167730616 

21)

\section{Tartışma}

Türkçe öğretmen adaylarının yabancı dil olarak Türkçe öğretimi ile ilgili görüşlerinde en dikkat çeken bulgulardan biri kültüre yapılan vurgudur. Öğrencileri motive etmek ve kaygılarını azaltmak için ders içeriğinin Türk kültürüne göre yapılandırılmasının önemi araştırmanın katılımcıları tarafından dile getirilmiştir. Bu sonuç alanyazında da yer almaktadır. Yabancı dil olarak Türkçe öğretiminde kültür aktarımının ne denli önemli olduğu ortaya konmaktadır. Moralı ve Göçer (2019) çalışmalarında çağdaş yabancı dil öğretim yaklaşımlarında dili öğretmenin yanı sıra kültürü de öğretmenin gerekli olduğunu belirtmişlerdir. Caner, Direkçi ve Kurt (2019) yabancı dil olarak Türkçe öğretiminde kültürel aktarımın olumlu getirilerini ayrıntılı olarak sunmuşlardır. Ancak öğretim sürecini sırf kültürel aktarımla şekillendirmenin ve kültürü; dil, bilgi ve becerilerinin önünde tutmanın abartılmaması gerektiğini belirtmişlerdir.

Bu çalışmaya katılan Türkçe öğretmen adayları yabancı dil olarak Türkçe öğretimi uygulamalarına ilişkin strateji, yöntem, teknik ve araç-gereç çeşitliliğinin olumlu etkileri konusunda görüşler ortaya koymuşlardır. Bu sonuç Kocaman (2012) ve Tosun'un (2012) çalışmalarında detaylı şekilde ifade edilmiştir. Buna göre yabancı dil öğretiminde çağdaş kuramları temel alan öğretme-öğrenme yaklaşımlarındaki değişimleri içeren ve özellikle işlevsel dil öğretim yaklaşımlarının başarı ve verimi artırdığı ortaya konmaktadır. Yabancı dil olarak Türkçe öğretiminde yöntem konusu ele alınırken öğrencilerin ihtiyaçlarını belirlemenin önemli olduğu birçok araştırmada (Başar \& Akbulut, 2016; Boylu \& Çangal, 2014; Koçer, 2013; Tok \& Yıgın, 2013) ortaya konmuştur. Eğer öğrencilerin ihtiyaçları belirlenirse yabancı dil öğretiminin niteliği sadece öğretim yöntem tekniklerini belirlemekle sınırlandırılmayacak ve daha geniş ölçekte eğitim programlarının oluşturulması ile öğretimin planlanmasına katkı sağlanacağı üzerinde durulmaktadır. Öğrencinin hangi ülkede bulunduğunun dahi öğretim yaklaşımlarını etkileyebileceği ve Türkçe öğrenme ihtiyaçları ve amaçlarının farklılaşabileceği belirtilmektedir. Bu çalışmaya katılan öğretmen adayları yabancı öğrencileri Türkçe öğrenirken motive etmek ve onların kaygılarını azaltabilmek için öğretim yöntem ve teknikleri çeşitlendirmenin gerekliliğine vurgu yapmışlardır. Biçer’in çalışmasında (2016), öğrencilerin oyun ve eğlenceli yöntemtekniklerin kullanılması sonucunda motive oldukları ortaya konmuştur. Bu çalışmanın mesleğe başlamadan önce Türkçe öğretmen adaylarının yöntem, teknik, bilgi ve yeterliklerini artırması açısından önemli ve değerli sonuçlar içerdiği söylenebilir.

Türkçe öğretmen adayları, yabancı dil öğreten Türkçe eğitimcilerinin sayısının artmasına ve mesleki yeterliklerinin geliştirilmesine gerek olduğunu belirtmişlerdir. Balcı'ya (2016) göre, ne yurt içinde ne yurt dışında yabancı dil olarak Türkçe öğretimi işin eğitimini almış uzman kişiler tarafından yürütülmektedir. Örneğin bu konu ile ilgili Alptekin (2012) ve Bayraktaroğlu (2012) da araştırma yapmışlardır. Türkiye'de yabancı dil eğitiminde yöntemsel hatalar olduğuna, dil planlamasının yapılmadığına ve Avrupa'daki uygulamalardan geri kalındığına yönelik görüşler ortaya koymuşlardır. Bu sorunları ortadan kaldırmaya ilişkin yükseköğretimde yabancı dil eğitim uygulamalarının niteliğinin artırılması gerektiğine değinmişlerdir.

Bu çalışmada Türkçe öğretmen adayları ileride mesleğe başlayacakları zaman yabancı öğrencilerini hangi açllardan geliştireceklerine ve kazanımlara ilişkin önemli konulara değinmişlerdir. Örneğin, Türkçeyi güzel ve akıcı konuşmak, Türkçeyi günlük hayatta etkili kullanabilme, Türkçe anlama becerilerini geliştirme, yabancı dilden arındırılmış cümleler kurabilme ve sözcük dağarcığını geliştirme gibi kazanımlar ön plana çıkmıştır. Göçen (2020) günümüzde yabancı dil öğretiminde günlük hayatla

\footnotetext{
Adres | Address

RumeliDE Dil ve Edebiyat Araştırmaları Dergisi $\quad$ RumeliDE Journal of Language and Literature Studies Osmanağa Mahallesi, Mürver Çiçeği Sokak, No:14/8 $\quad$ Osmanağa Mahallesi, Mürver Çiçeği Sokak, No:14/8 Kadıköy - ÍSTANBUL / TÜRKIYE 34714 Kadıköy - ISTANBUL / TURKEY 34714 e-posta: editor@rumelide.com e-mail: editor@rumelide.com, tel: +90 505 7958124, +90 2167730616 phone: +90 505 7958124, +90 2167730616
} 
Teaching Turkish as a foreign language in Cyprus through the view of Turkish teacher candidates / S. Güntaş; A. Güneyli; B. Gökbulut (pp. 1-21)

bağ kurma, öğrenciler arası etkileşimi artırma ve görev odaklılık gibi dilin uygulanmalı öğretimine odaklanılması gerektiğini belirtmektedir.

Bu çalışmada Türkçe öğretmen adayları anadili ve yabancı dil olarak Türkçenin öğretiminin farkına ilişkin görüşler ortaya koymuşlardır; bu konu alanyazında da yer almaktadır. Mete ve Gürsoy’un (2013) araştırmasında Türkçeyi yabancı dil olarak öğreten ve anadili olarak öğreten öğretmenlerin farklı alan ve mesleki özelliklere sahip olmaları gerektiğine dikkat çekmişlerdir. Mete ve Gürsoy (2013), Türkiye’de yabancı dil olarak Türkçe öğretimi verecek eğiticilerin yeterlilikleri konusunda kuramsal olarak çalışmaların yeterli düzeyde yapılmadığını ortaya koymuşlar ve bu konunun önemine vurgu yapmışlardır. Örneğin, bu çalışmada Türkçe öğretmen adayları dilbilgisi öğretim yönteminin ana dili veya yabancı dil olarak öğretime göre değiş̧ebileceği üzerinde durmuşlardır. Bu sonuç, öğretmen adaylarının farkı anlayıp içselleştirdiğine işaret etmektedir. Ayrıca öğretim stratejileri, ilkeleri vb. konularda farklılıklara değinilmiştir.

Yabancı dil olarak Türkçe öğretiminin sorunlarına ilişkin öğretmen adayları birtakım görüşler ortaya koymuşlardır. Konuşma ve telaffuz sorunu bu sorunlar içerisinde sıklıkla dile getirilmiştir. Bu sonuç, Biçer, Çoban ve Bakır'ın çalışmasında (2014) da ortaya çıkmış ve nedenlerinden biri olarak öğreticilerin hızlı konuşmaları gösterilmiştir. Bunun yanında yazma konusunda sorunların yaşandığı ifade edilmiştir. $\mathrm{Bu}$ bulgu ise Arslan ve Kılıç'ın (2015) çalışmasındaki bulgularla örtüşmektedir. Yabancı dil olarak Türkçe öğretimindeki sorunların çözümünde öncelikli olarak eğiticilerin mesleki ve alan yeterliklerini artırmanın önemli olduğu ifade edilmiştir. Korkmaz (2018), Türkiye'de yabancı dil eğitiminde yaşanan sorunların eğitmenlere eğitim verilmesi yolu ile aşılabileceğini belirtmektedir.

\section{Sonuç ve öneriler}

Öğretmen adayları, yabancı dil olarak Türkçe öğretecek eğitimcilerin anadillerine hâkim olmalarının yanı sıra yabancı dil bilmeleri gerektiğini belirtmişlerdir. Bazı kuralları açıklamak ve sınıf içi yönergeler verebilmek için özellikle başlangıç döneminde yabancı dile gereksinim duyulmaktadır. Bu nedenle nitelikli bir yabancı dil eğitimi alınması ve eğitimin sürecinin sonucunda öğreticilerin belgeye sahip olmaları gerektiği söylenebilir.

Türkçe öğretmen adayları ileride mesleğe başlayacakları ve yabancılara Türkçe öğretecekleri zaman en önemli kazanımın Türkçeyi günlük yaşamda kullanabilmek olduğunu belirtmişlerdir. Bu nedenle hem çevrimiçi hem de yüz yüze eğitim ortamlarında dili günlük yaşamda kullanmanın, özellikle de dinlemekonuşma becerisine yönelik etkinliklere ağırlık vermenin çok önemli olduğu söylenebilir.

Türkçe öğretmen adayları, bir öğretmen gözüyle yabancılara Türkçe öğretiminin nasıl yapılması gerektiğini ve kazanımların neler olması gerektiğini düşünme imkânı yakalamışlardır. Yabancılara Türkçe öğretiminde öğreticilerin, bilişsel kazanımların yanı sıra duyuşsal kazanımları da geliştirmeye yönelik çalışmalar yürütmesi gerekmektedir. Böylelikle Türkçeyi sevdirmenin mümkün olacağı üzerinde durulmuştur.

Türkçe öğretmen adaylarının yabancılara Türkçe öğretiminde içerikte neler olması gerektiği konusundaki görüşleri incelendiğinde, kültür, tarih ve coğrafyanın ön plana çıktığı görülmektedir. Özellikle e-öğrenme ortamlarında kültür, tarih ve coğrafya ile ilgili video ve görsellere rahatlıkla ulaşılabileceği söylenebilir. Bu durum, yabancılara Türkçe öğretilirken çok uyaranlı bir öğrenme ortamının (görsel, işitsel, görsel-işitsel) oluşturulmasının önemli olduğunu göstermektedir.

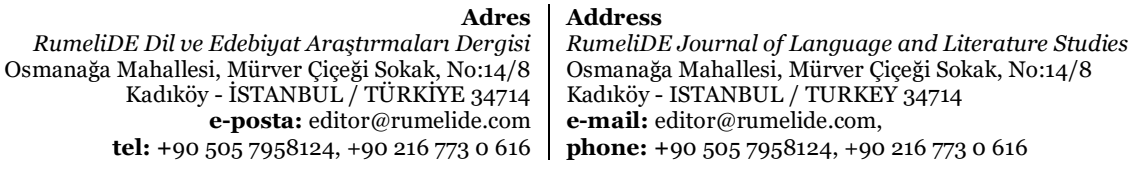



21)

Çalışmada öğretmen adaylarının sunuş yoluyla öğretim stratejisinin daha yoğun kullanıldığına vurgu yapmaları dikkate değer bir bulgudur. Oysa buluş ve araştırma yoluyla öğretim stratejilerine daha çok yer verilmesi gerektiği söylenebilir. Buluş ve araştırma yoluyla öğrenme, dil eğitiminde öğrencinin aktif olmasını ve uygulama yapmasını sağlamaktadır.

$\mathrm{Bu}$ araştırma sonucunda, Türkçenin anadili olarak öğretimi ve yabancı dil olarak öğretimi konusunda öğretmen adaylarının görüssleri nesnel veya bilimsel bir bakış açısıyla yazılmış değildir. Kolaydır, zordur, önemlidir şeklinde sübjektif görüşler ifade edilmiştir; bu sonuçtan hareketle Türkçe öğretmenliği bölümlerinde lisans eğitiminde yer alan Yabancı Dil Olarak Türkçe Öğretimi dersinde Türkçenin anadili ve yabancı dil olarak öğretim farklılıklarına değinilmesi gerekmektedir.

Öğretmen adaylarının değindiği gibi motivasyonu artırma ve kaygıyı azaltmaya yönelik yabancılara Türkçe öğretiminde yöntem çeşitliliğine yer verilmeli, Türk kültürüyle ilgili konular içerikte yer almalıdır.

Yabancı dil olarak Türkçe öğretiminde sorunların çözümüne ilişkin bu araştırmada öğretmen adaylarının ortaya koyduğu görüşlerden yararlanılması önerilebilir. Öğretimi basitleştirme, hazırbulunuşluğu ortaya çıkarma, bol etkinlik yapma, motivasyona önem verme gibi öneriler dikkate alınabilir.

\section{Kaynakça}

Aktoprak, A., Yiğit, P., \& Güneyli, A. (2018). Attitudes of primary school teachers toward multicultural education. Quality \& Quantity, 52(1), 181-194.

Albayrak, F., ve Erciyas, O. (2019). Kuzey Kıbrıs Türk Cumhuriyeti’nde Türkçenin yabancı dil olarak öğretimi. Rauf Raif Denktaş ve Dr. Fazıl Küçük I. Uluslararası Kıbrıs Araştırmaları Sempozyumu Bildiri Tam Metin Kitabı, (Ed. G. Y. Peler ve G. Arıklı), ss. 45-65, Hiperyayın.

Alptekin, C. (2012). Yabancı dil eğitiminde öğretmen yetiştiren akademisyenlerin nitelikleri. İçinde Ed. A. Sarıçoban ve H. Öz, Türkiye'de Yabancı dil eğitiminde eğilim ne olmah? 1. Yabancı Dil Eğitimi Çalıştayı Bildirileri, 12-13 Kasım 2012 (ss. 15-26). Hacettepe Üniversitesi.

Arı, Ş. (2010). Kuzey Kıbrıs Türk Cumhuriyeti’nde ilköğretimin ikinci kademesinde öğrenim gören yabancılara Türkçe öğretimi üzerine bir değerlendirme (Yayınlanmamış Doktora Tezi). Gazi Üniversitesi, Eğitim Bilimleri Enstitüsü, Ankara.

Arı, Ş. (2013). Kuzey Kıbrıs Türk Cumhuriyeti’nde yabancı dil olarak Türkçe öğretimi. İçinde Prof. Dr. Abdurrahman Güzel Armağanı: Türkçenin Eğitimi ve Öğretimi, (Ed. H. Parlakyıldız ve C. Demir), Akçă̆.

Arslan, M. ve Kılıç, E. (2015). Yabancı dil olarak Türkçe öğretiminde yazma becerisinin gelişiminde karşılaşlan sorunlar: Bosna Hersek örneği. 5(2), 169-182. https://dergipark.org.tr/ en/pub/kusbd/issue/19381/205631 adresinden 11.09.2021 tarihinde alınmıştır.

Aytaçlı, B. (2012). Durum çalışmasına ayrıntılı bir bakış. Adnan Menderes Üniversitesi Eğitim Fakültesi Eğitim Bilimleri Dergisi, 3(1), 1-9.

https://dergipark.org.tr/en/pub/aduefebder/issue/ 33889/375231 adresinden 11.09.2021 tarihinde alınmıştır.

Balc1, E. (2017). Perceptions on blended learning: A study on student and instructor experiences in an English Preparatory Program (Yayımlanmamış yüksek lisans tezi). Pamukkale Üniversitesi, Eğitim Bilimleri Enstitüsü, Denizli.

Başar, U. ve Akbulut, E. (2016). Yabancılara Türkçe öğretiminde öğrenen ihtiyaçlarının belirlenmesi: Yunus Emre Enstitüsü Tiflis Türk Kültür Merkezi örneği. Uluslararası Türkçe Edebiyat Kültür Ĕ̆itim Dergisi, 5(2), 1005-1020. http://dx.doi.org/10.7884/teke.673

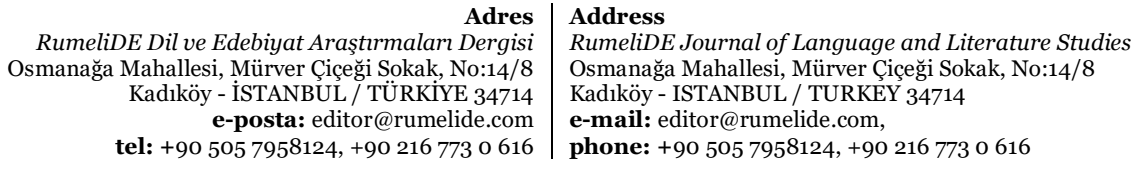


Teaching Turkish as a foreign language in Cyprus through the view of Turkish teacher candidates / S. Güntaş; A. Güneyli; B. Gökbulut (pp. 1-21)

Bayraktaroğlu, S. (2012, 12-13 Kasım).Yabancı dil eğitimi gerçeği, yabancı dille eğitim yanılgısı. Türkiye'de yabancı dil eğitiminde eğilim ne olmalı? Hacettepe Üniversitesi Eğitim Fakültesi İngiliz Dili Eğitimi Anabilim Dalı I. Yabancı Dil Eğitimi Çalıştayı Bildirileri, Ankara.

Baxter, P. \& Jack, S. (2008). Qualitative case study methodology: Study design and implementation for novice researchers. The Qualitative Report, 13(4), 544-559. https://doi.org/ 10.46743/2160$3715 / 2008.1573$

Biçer, N., Çoban, İ. ve Bakır, S. (2014). Türkçe öğrenen yabancı öğrencilerin karşılaştığı sorunlar: Atatürk üniversitesi örneği. Journal of International Social Research, 7(29), 125-135. https://www.bilgicik.com/wp-content/uploads/2018/o5/bicer_nursat_vdx.pdf adresinden alındığı tarih 11.09.2021.

Biçer, N. (2016). Yabancılara Türkçe öğretiminde motivasyona ilişkin öğrenci görüşleri ve sınıf içi gözlemler. Ana Dili Ĕgitimi Dergisi, 4(1), 84-99. https://www.anadiliegitimi.com/en/download/ article-file/226777 adresinden alındığı tarih 11.09.2021.

Boylu, E., ve Çangal, Ö. (2014). Yabancılara Türkçe öğretiminde dil ihtiyaç analizi: İran örneği. International Journal of Language Academy, 2(4), 127-151. http://dx.doi.org/10.18033/ ijla.152

Büyüköztürk, Ş., Çakmak, E. K., Akgün, Ö. E., Karadeniz, Ş., ve Demirel, F. (2012). Bilimsel araştırma yöntemleri (10. Baskı). Pegem Akademi.

Caner, M., Direkçi, B., ve Kurt, B. (2019). Yabancı dil olarak Türkçe öğretiminde kültür aktarımına ilişkin öğretmen adaylarının görüşleri. Dil Eğitimi ve Araştırmaları Dergisi, 5(2), 76-92. https://doi.org/10.31464/jlere.603161

Creswell, J. W., \& Clark, V. L. P. (2017). Designing and conducting mixed methods research. Sage.

Çiçek, Ş. A. (2017). Okul öncesi eğitim kurumlarmdaki Türkçe bilmeyen 3-6 yaş çocuklarmın karşılaştıkları sorunlar hakkında öğretmen görüssleri (Yayımlanmamış Yüksek Lisans Tezi). Lisansüstü Eğitim Enstitüsü, Doğu Akdeniz Üniversitesi, Gazi Mağusa.

Dağdelen, D. (2015). Yabancılara Türkçe öğretimi programının öğretmen ve öğrenci görüşlerine göre değerlendirilmesi (Yayımlanmamış Yüksek Lisans Tezi). Lisansüstü Eğitim Enstitüsü, Doğu Akdeniz Üniversitesi, Gazi Mağusa.

Demircan, Ö. (1990). Yabancı dil öğretim yöntemleri. Ekin Eğitim.

Egeli, S., ve Barut, Y. (2020). Anadili Türkçe olmayan yabancı uyruklu öğrencilerin okul ortamında yaşadıkları problemler. Cyprus Turkish Journal of Psychiatry \& Psychology, 2(3), 171-79. https://doi.org/10.35365/ctjpp.20.03.20

Faslı, F. G. (2018). Yabancı dil olarak Türkçe öğretim programının akademisyen ve öğrenci görüşleri temelinde değerlendirilmesi (Yayımlanmamış Doktora Tezi). Eğitim Bilimleri Enstitüsü, Yakın Doğu Üniversitesi, Lefkoşa.

Göçen, G. (2020). Turkish as a foreign language learners' use of vocabulary learning strategies. Journal of Language and Linguistic Studies, 16(1), 316-332. https://doi.org/ 10.17263/jlls.712838

Güneyli, A., ve Gökçebağ, D. (2018). Türkçeyi yabancı dil olarak öğrenen Kıbrıslı Rumların kaygı düzeylerinin incelenmesi. Turkish Studies, 13(4), 669-683. http://dx.doi.org/10.7827/ TurkishStudies.12757

Güntaş, S., Güneyli, A., ve Gökbulut, B. (2020). Evaluation of e-learning and self-efficacy levels of Turkish teacher candidates in Turkish education as a foreign language course based on blended learning. Revista Argentina de Clïnica Psicológica, 29(5), 834-847. Doi: 10.24205/03276716.2020.1081

Güntaş, S., Güneyli, A., ve Gökbulut, B. (2021). Assessment of the effectiveness of blended learning in foreign language teaching: Turkish language case. Laplage em Revista, 7(Extra-B), 468-484. https://doi.org/10.24115/S2446-622020217Extra-B926p.468-484

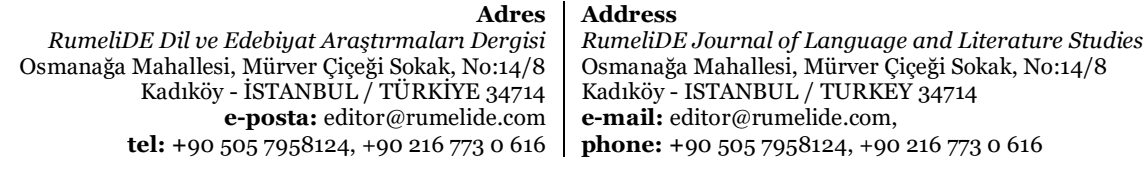


Türkçe öğretmen adaylarının gözünden Kıbrıs’ta yabancı dil olarak Türkçe öğretimi / S. Güntaş; A. Güneyli; B. Gökbulut (pp. 121)

Kirazlı, N. ve Ateş M. (2016). Türkçenin yabancı dil olarak öğretiminde görsel ve işitsel materyal kullanımı. Ist International Academic Research Congress (INES 2016) Tam Metin Kitabı, ss. 3290-3299.

KKTC Milli Eğitim ve Kültür Bakanlığı (MEKB). (2020). Yabancılara Yönelik Türkçe Destek Programı 6-12 Yaş Başlangıç Seviyesi. Lefkoşa.

KKTC Milli Ĕ̆itim ve Kültür Bakanlığı (MEKB). (2020). Yabancılara Yönelik Türkçe Destek Programı 13-17 Yaş Başlangıç Seviyesi. Lefkoşa.

Kocaman, A. (2012, 12-13 Kasım). Yabancı dil öğretiminde yöntem ve ötesi. Türkiye'de yabancı dil eğitiminde eğilim ne olmalı? Hacettepe Üniversitesi Eğitim Fakültesi İngiliz Dili Eğitimi Anabilim Dalı I. Yabancı Dil Eğitimi Çalıştayı Bildirileri, Ankara.

Koçer, Ö. (2013). Program geliştirmenin ilk basamağı: yabancı dil olarak Türkçe öğretiminde ihtiyaç ve durum analizi. Eğitim ve Bilim, 38(169), 159-174. http://egitimvebilim.ted.org.tr/ index.php/EB/article/view/1917 adresinden alındığı tarih 11.09.2021.

Korkmaz, E. (2018). Yabancılara Türkçe öğretiminde yaşanan bazı sorunlar ve çözümleri. Kahramanmaraş Sütçü İmam Üniversitesi Sosyal Bilimler Dergisi, 15(1), 89-104. https://dergipark.org.tr/en/pub/ksusbd/issue/37007/329420 adresinden alındığı tarih 11.09.2021.

Mete F. (2015). Dil ve yabancı/ ikinci dil eğitimi kavramları. İçinde Yabancı dil olarak Türkçe öğretimi metodolojisi. Ed. A. Sarıçoban, ss. 158-190. Anı.

Mete, F. ve Gürsoy, Ü. (2013). Yabancı dil olarak Türkçe öğretiminde öğretmen yeterliklerine ilişkin görüşler. Hacettepe Üniversitesi Eğitim Fakültesi Dergisi, 28(3), 343-357. https://dergipark.org.tr/en/pub/hunefd/issue/7791/101927 adresinden alındığ 11.09.2021.

Miçooğulları, M. (2020). Yabancılara Yönelik Türkçe Destek Öğretim Programlarının karşılaştırmalı olarak değerlendirilmesi: KKTC örneği. Sinerji Uluslararası Alan Eğitimi Araştırmaları Dergisi, 1(2), 67-82. https://dergipark.org.tr/en/download/article-file/1380924_adresinden alındığı tarih 11.09.2021.

Moralı, G. ve Göçer, A. (2019). Yabancı dil olarak Türkçe öğretiminde kültür paylaşımına yönelik öğretmen görüşleri. Ana Dili Ĕ̆itimi Dergisi, 7(4), 1115-1129. http://www.anadiliegitimi.com/ en/download/article-file/844066 adresinden alındığı tarih 11.09.2021.

Tok, M. ve Yıgın, M. (2013). Yabancı uyruklu öğrencilerin Türkçe öğrenme nedenlerine ilişkin bir durum çalışması. Dil ve Edebiyat Egitimi Dergisi, 2(8), 132-147. http://oaji.net/articles/2014/10691406114544.pdf adresinden alındığ tarih 11.09.2021.

Tosun, C. (2012, 12-13 Kasım).Yurdumuzda yabancı dil öğretme ve öğrenme sürecinde başarısızlı̆̆ın nedeni yöntem mi? Türkiye'de yabancı dil eğitiminde eğilim ne olmalı? Hacettepe Üniversitesi Eğitim Fakültesi İngiliz Dili Eğitimi Anabilim Dalı I. Yabancı Dil Eğitimi Çalıştayı Bildirileri, Ankara.

Uzun, E. (2012). Yabancılara Türkçe öğretiminde yeni gelişmeler üzerine. İçinde Yabancı dil olarak Türkçe öğretimi. Ed. A. Kılınç ve A. Şahin, ss. 341-345. Pegem Akademi.

Yıldırım, A. ve Şimşek, H. (2008). Nitel araştırma yöntemleri. (7. Baskı). Seçkin.

Yıldız, Ü. ve Tunçel, H. (2014). Yabancı dil olarak Türkçe öğretiminde program ve materyal. İçinde Yabancı dil olarak Türkçe öğretimi. Ed. A. Kılınç ve A. Şahin, ss. 175-205. Pegem Akademi.

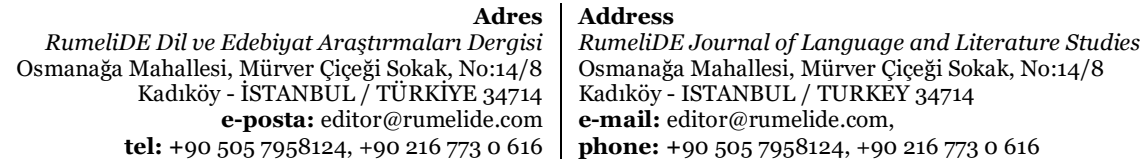

